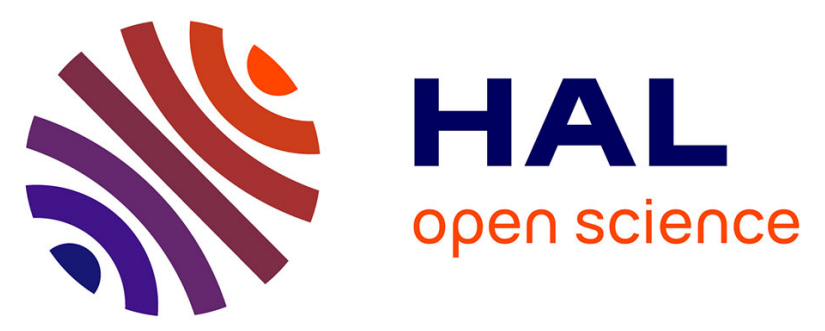

\title{
High Oxygen Reduction Reaction Performances of Cathode Materials Combining Polyoxometalates, Coordination Complexes, and Carboneous Supports
} Shuangshuang Zhang, Olivier Oms, Long Hao, Rongji Liu, Meng Wang, Yaqin Zhang, Hong-Yan He, Anne Dolbecq, Jérôme Marrot, Bineta Keita, et al.

\section{To cite this version:}

Shuangshuang Zhang, Olivier Oms, Long Hao, Rongji Liu, Meng Wang, et al.. High Oxygen Reduction Reaction Performances of Cathode Materials Combining Polyoxometalates, Coordination Complexes, and Carboneous Supports. ACS Applied Materials \& Interfaces, 2017, 9 (44), pp.38486-38498. 10.1021/acsami.7b10989 . hal-02336638

\section{HAL Id: hal-02336638 \\ https://hal.science/hal-02336638}

Submitted on 30 Oct 2019

HAL is a multi-disciplinary open access archive for the deposit and dissemination of scientific research documents, whether they are published or not. The documents may come from teaching and research institutions in France or abroad, or from public or private research centers.
L'archive ouverte pluridisciplinaire HAL, est destinée au dépôt et à la diffusion de documents scientifiques de niveau recherche, publiés ou non, émanant des établissements d'enseignement et de recherche français ou étrangers, des laboratoires publics ou privés. 


\section{High Oxygen Reduction Reaction Performances of Cathode Materials Combining}

Polyoxometalates, Coordination Complexes and Carboneous Supports

Shuangshuang Zhang, ${ }^{\dagger}{ }^{\dagger}$ Olivier Oms, ${ }^{\ddagger}$ Long Hao, ${ }^{\prime \prime}$ Rongji Liu, ${ }^{\dagger}$ Meng Wang, ${ }^{\dagger}$ Yaqin Zhang, ${ }^{\dagger}$ Hong-Yan He, ${ }^{*}{ }^{\dagger}$ Anne Dolbecq, ${ }^{\ddagger}$ Jérôme Marrot, ${ }^{\ddagger}$ Bineta Keita, ${ }^{\S, \nabla}$ Linjie Zhi, " Pierre Mialane,,$"$ Bin Li" and Guangjin Zhang ${ }^{*, \dagger}$

${ }^{\dagger}$ Key Laboratory of Green Process and Engineering, Institute of Process Engineering, Chinese Academy of Sciences, 100190, Beijing, China.

E-mail: hyhe@ipe.ac.cn.

E-mail: zhanggi@ipe.ac.cn.

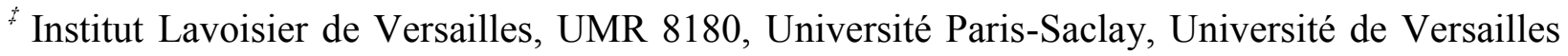
Saint-Quentin en Yvelines, 45 Avenue des Etats-Unis, 78035 Versailles cedex (France). E-mail: pierre.mialane@uvsq.fr.

${ }^{s}$ Laboratoire de Chimie-Physique, UMR 8000 CNRS, Université Paris-Sud Orsay, F-91405, France.

"Key Laboratory of Nanosystem and Hierarchical Fabrication National Center for Nanoscience and Technology, 100190, Beijing, China.

"Zhengzhou Tobacco Research Institute of CNTC, 450001, Zhengzhou, China. 
${ }^{\perp}$ College of Chemistry, Chemical Engineering and Materials Science, Collaborative Innovation Center of Functionalized Probes for Chemical Imaging in Universities of Shandong, Key Laboratory of Molecular and Nano Probes, Ministry of Education, Institute of Molecular and Nano Science, Shandong Normal University, Jinan 250014, P. R. China.

\section{${ }^{\nabla}$ Retired}




\section{ABSTRACT}

A series of carbonaceous-supported precious metal-free polyoxometalate (POM)-based composites which can be easily synthesized on a large scale has been shown to act as efficient cathode materials for the oxygen reduction reaction (ORR) in neutral or basic media via a fourelectron mechanism with high durability. Moreover, exploiting the versatility of the considered system, its activity has been optimized by the judicious choice of the $3 \mathrm{~d}$ metals incorporated in the $\left\{\left(\mathrm{PW}_{9}\right)_{2} \mathrm{M}_{7}\right\}(\mathrm{M}=\mathrm{Co}, \mathrm{Ni})$ POM core, the POM counter-ions and the support (thermalized triazine-based frameworks (TTFs), fluorine-doped TTF (TTF-F), reduced graphene oxide or carbon Vulcan XC-72. In particular, for $\left\{\left(\mathrm{PW}_{9}\right)_{2} \mathrm{Ni}_{7}\right\} /\left\{\mathrm{Cu}(\text { ethylenediamine })_{2}\right\} / \mathrm{TTF}-\mathrm{F}$, the overpotential required to drive the ORR compare well with those of $\mathrm{Pt} / \mathrm{C}$. This outstanding ORR electrocatalytic activity is in link with two synergistic effects, due to the binary combination of the $\mathrm{Cu}$ and $\mathrm{Ni}$ centers and the strong interaction between the POM molecules and the porous and highly conducting TTF-F framework. To our knowledge, $\left\{\left(\mathrm{PW}_{9}\right)_{2} \mathrm{Ni}_{7}\right\} /\left\{\mathrm{Cu}(\text { ethylenediamine })_{2}\right\} / \mathrm{TTF}-\mathrm{F}$ represents the first example of POM-based noble metal-free ORR electrocatalyst possessing both comparable ORR electrocatalytic activity and much higher stability than those of $\mathrm{Pt} / \mathrm{C}$ in neutral medium.

Keywords: carbonaceous materials, oxygen reduction reaction, polyoxometalate, neutral medium, basic medium 


\section{INTRODUCTION}

Recently, extensive research has been performed on Microbial fuel cells (MFCs) that will be applied to the conversion of biomass into electricity and the treatment of wastewaters through biological oxidization at the anode and chemical reduction at the cathode. In MFCs, the electrocatalysts works at neutral conditions to maintain the biological activity. However, the lack of cheap and organics-resistant oxygen reduction reaction (ORR) catalysts remains a key concern for their large-scale application. ${ }^{1}$ Elaborating efficient and stable electrocatalysts for the ORR is thus of primarily importance for the development of MFCs, but more generally for high-capacity energy systems, such as metal-air batteries ${ }^{2,3}$ and polymer electrolyte membrane fuel cells. ${ }^{4-7}$ Platinum nanoparticles (NPs) have been evidenced to act as efficient cathode electrode materials. Nevertheless, the high price of platinum explains the tremendous efforts that are currently made in order to elaborate Pt-free ORR catalysts -and more generally non-precious metal catalysts (NPMCs). ${ }^{8}$

Importantly, a polyaniline-FeCo-C bimetallic catalyst with remarkable stability and ORR activity has been reported in $2011 .^{9}$ Besides, cobalt and manganese oxides have been identified as stable ORR catalysts. ${ }^{10}$ The relatively poor electrical conductivity of these transition metal oxides can be overcome by associating them with zeolite ${ }^{11}$ or carbon. ${ }^{12}$ Obviously, the choice of the carbon support (carbon nanotubes, reduced graphene oxide (rGO), glassy carbon etc.) plays a crucial role on the ORR performances. ${ }^{13}$ Such hybrid materials associating cheap metal oxides and carbon support can represent a good alternative to precious metal catalysts. However, they still exhibit limited ORR activity, even if it has been shown that their performances can be enhanced by introducing native oxygen defects. ${ }^{14}$ For attractive alternative to Pt-based ORR electrocatalysts, it is thus still challenging to develop less expensive cathode materials capable 
even in neutral medium to proceed through a highly effective four-electron pathway at large current densities, low electrocatalyst loading and at overpotential close to that of Pt.

Recently, polyoxometalates (POMs) - which can be defined as molecular oxides incorporating metals in high oxidation state $\left(\mathrm{W}^{\mathrm{VI}}, \mathrm{Mo}^{\mathrm{VI}}, \mathrm{V}^{\mathrm{V}}, \ldots\right)^{15-23}$-have emerged as a new platform for the synthesis of new nanocarbon composites. ${ }^{24,25}$ POMs have attracted significant contemporary interest because of their unique functionality, making them active constituents in various materials, such as catalysis and medicine. ${ }^{26,27}$ The POMs constituting these electrodes possess numerous advantages: i) they can be easily prepared in large quantities, ii) they exhibit a high thermal stability, iii) their composition can be finely tuned, iv) despite their complexity, their structures can be accurately determined, allowing accurately tuning the activity through structural design and mechanistic considerations, v) their anionic character allows to readily associate them with chosen cationic species, permitting to form water-insoluble species but also to combine the properties of the anionic and cationic moieties, vi) they spontaneously strongly interact with carbon supports via electrostatic interactions or charge transfer. ${ }^{28-30}$ This spontaneous attraction without any other linkers is highly beneficial for ORR by the maximal exposure of metal catalytic sites of POMs to the surrounding electrolytes and facile electron transfer at the bare interface between POMs and support, and vii) they possess good proton and electron reservoir abilities, allowing electron and proton burst transmission. However, the POMs have also some main drawbacks which made them hardly be applied in ORR electrocatalyst. First of all, POMs are mostly bad conductors which are considered unfavorable for electron transportation. Secondly, most POMs are highly soluble in the working media which made them unstable when used as modified electrode. More importantly, lack of active sites in most POMs is essential drawbacks for their further application as ORR catalysts. Thus, the use of POMs-derived composites as the 
catalysts for ORR has rarely been reported so far. Only recently, we evidenced that POMs embedding cobalt centers and associated to the carbon Vulcan XC-72 can represent cathode materials for ORR electrocatalysis in neutral and basic media, with however limited ORR performances. ${ }^{31}$ To overcome these drawbacks, we have designed and synthesized a novel kind of POM molecules that embedded the ORR active elements such as $\mathrm{Ni}$, $\mathrm{Co}$ and $\mathrm{Cu}$ in the POM molecules. And by coordinate with organic ligands, such POMs are unsolvable in water, which make it possible for ORR catalyst as modified electrodes.

In parallel, some of us reported on various triazine-based frameworks as an emerging class of metal-free materials for effective ORR electrocatalysts in basic medium. ${ }^{32}$ These highly conductive frameworks can be easily doped by various heteroatoms, allowing to improve their catalytic selectivity or activity. But they can also be used as supports for ORR electrocatalysts.

Herein, we report on an innovative approach for the fabrication of outstanding noble metalfree ORR electrocatalysts based on multi-metallic POMs (Figure 1), classical cationic coordination complexes and selected carbonaceous materials. Our strategy to achieve this goal was to develop hybrids able to promote four-electron ORR pathway though electrocatalytic processes induced by two synergistic effects due to, respectively, the POM and its associated cationic coordination complex and the strong interactions between the POM and a highly conducting carbonaceous material which is also active as ORR electrocatalyst. We evidence that a judicious combination of the POM-inserted 3d metals (Ni vs. Co), the POM counter-ion (noninnocent small copper complexes vs. innocent ammonium cations) and the support material (thermalized triazine-based frameworks (TTFs) and fluorine-doped TTF (TTF-F) vs. reduced grapheme oxide (rGO) and carbon Vulcan XC-72 (C)) allow the design of low-cost cathodes which can possess higher ORR performances than $\mathrm{Pt} / \mathrm{C}(20 \mathrm{wt} \% \mathrm{Pt})$ in neutral medium. 


\section{EXPERIMENTAL SECTION}

2.1 Synthesis and characterizations of POMS. $\mathrm{K}_{6}\left[\mathrm{P}_{2} \mathrm{~W}_{18} \mathrm{O}_{62}\right] \cdot 14 \mathrm{H}_{2} \mathrm{O},{ }^{33} \quad \mathrm{Na}_{9}[\mathrm{~A}-$ $\left.\mathrm{PW}_{9} \mathrm{O}_{34}\right] \cdot 7 \mathrm{H}_{2} \mathrm{O},{ }^{33} \quad\left[\mathrm{H}_{2} \mathrm{O}_{3} \mathrm{PC}(\mathrm{OH})\left(\mathrm{C}_{3} \mathrm{H}_{6} \mathrm{NH}_{2}\right) \mathrm{PO}_{3} \mathrm{H}_{2}\right]$ (alendronic acid), ${ }^{34} \mathrm{Na}_{9}\left(\mathrm{NH}_{4}\right)_{5}[\{(\mathrm{~B}-\alpha-$ $\left.\left.\left.\mathrm{PW}_{9} \mathrm{O}_{34}\right) \mathrm{Co}_{3}(\mathrm{OH})\left(\mathrm{H}_{2} \mathrm{O}\right)_{2}(\mathrm{Ale})\right\}_{2} \mathrm{Co}\right] \cdot 35 \mathrm{H}_{2} \mathrm{O}\left(\mathrm{NaNH}_{4} \mathrm{Co}_{7}\right),{ }^{35} \quad\left(\mathrm{NH}_{4}\right)_{14}[\{(\mathrm{~B}-\alpha-$ $\left.\left.\left.\mathrm{PW}_{9} \mathrm{O}_{34}\right) \mathrm{Co}_{3}(\mathrm{OH})\left(\mathrm{H}_{2} \mathrm{O}\right)_{2}(\mathrm{Ale})\right\}_{2} \mathrm{Co}\right] \cdot 30 \mathrm{H}_{2} \mathrm{O}\left(\mathrm{NH}_{4} \mathrm{Co}_{7}\right),{ }^{35} \quad \mathrm{Na}_{7} \mathrm{~K}_{7}[\{(\mathrm{~B}-$ $\left.\left.\left.\mathrm{PW}_{9} \mathrm{O}_{34}\right) \mathrm{Ni}_{3}(\mathrm{OH})\left(\mathrm{H}_{2} \mathrm{O}\right)_{2}\left(\mathrm{O}_{3} \mathrm{PC}(\mathrm{O})\left(\mathrm{C}_{3} \mathrm{H}_{6} \mathrm{NH}_{3}\right) \mathrm{PO}_{3}\right)\right\}_{2} \mathrm{Ni}\right] \cdot 34 \mathrm{H}_{2} \mathrm{O}\left(\mathrm{NaKNi}_{7}\right)^{36}$ and $\mathrm{Na}_{3}\left(\mathrm{NH}_{4}\right)_{11}[\{(\mathrm{~B}-$ $\left.\left.\left.\mathrm{PW}_{9} \mathrm{O}_{34}\right) \mathrm{Ni}_{3}(\mathrm{OH})\left(\mathrm{H}_{2} \mathrm{O}\right)_{2}\left(\mathrm{O}_{3} \mathrm{PC}(\mathrm{O})\left(\mathrm{C}_{3} \mathrm{H}_{6} \mathrm{NH}_{3}\right) \mathrm{PO}_{3}\right)\right\}_{2} \mathrm{Ni}\right] \cdot 36 \mathrm{H}_{2} \mathrm{O} \quad\left(\mathbf{N H}_{\mathbf{4}} \mathbf{N i}_{7}\right){ }^{36}$ have been synthesized as previously described. All other chemicals were used as purchased without purification.

$\left[\mathbf{C u}(\mathbf{e n})_{2}\right]_{3}\left[\mathbf{P}_{\mathbf{2}} \mathbf{W}_{\mathbf{1 8}} \mathbf{O}_{\mathbf{6 2}}\right] \cdot \mathbf{2 0 H _ { 2 }} \mathrm{O}\left(\mathbf{C u P}_{\mathbf{2}} \mathbf{W}_{18}\right)$. A solution of $\mathrm{K}_{6}\left[\mathrm{P}_{2} \mathrm{~W}_{18} \mathrm{O}_{62}\right] \cdot 14 \mathrm{H}_{2} \mathrm{O}(160 \mathrm{mg}, 3.3$ $\left.\times 10^{-5} \mathrm{~mol}\right)$ in $2.5 \mathrm{~mL}$ of water was added dropwise to a solution of $\mathrm{Cu}(\mathrm{en})_{2}\left(\mathrm{NO}_{3}\right)_{2}(200 \mathrm{mg}$, $\left.6.5 \times 10^{-4} \mathrm{~mol}\right)$ in $2.5 \mathrm{~mL}$ of water. The resulting suspension was stirred for $15 \mathrm{mn}$., filtrated and washed with water $(4 \times 5 \mathrm{~mL})$, ethanol $(2 \times 5 \mathrm{~mL})$ and ether $(2 \times 10 \mathrm{~mL})$ to afford a purple powder (quantitative yield). IR: $v\left(\mathrm{~cm}^{-1}\right)=3504(\mathrm{br}), 3316(\mathrm{~m}), 3260(\mathrm{~m}), 3150(\mathrm{w}), 2955(\mathrm{w}), 2893(\mathrm{w})$, 1684(m), 1460(w), 1397(w), 1280(w), 1087(s), 1037(s), 964(s), 904(s), 761(vs), 695(sh), 598(w), 521(s), 471(m). EDX calc. (found) : W/Cu 6 (6.3); W/P 9 (8.5); Cu/P 1.5 (1.4).

\section{$\mathrm{Na}_{2}\left[\mathrm{Cu}(\mathrm{en})_{2}\right]_{6}\left[\left\{\left(\mathrm{PW}_{9} \mathrm{O}_{34}\right) \mathrm{Co}_{3}(\mathrm{OH})\left(\mathrm{H}_{2} \mathrm{O}\right)_{2}\left(\mathrm{O}_{3} \mathrm{PC}(\mathrm{O})\left(\mathrm{C}_{3} \mathrm{H}_{6} \mathrm{NH}_{3}\right) \mathrm{PO}_{3}\right)\right\}_{2} \mathrm{Co}\right] \cdot 45 \mathrm{H}_{2} \mathrm{O}$}

$\left(\mathrm{Cu}_{6} \mathrm{Co}_{7}\right) . \mathrm{NaNH}_{4} \mathrm{Co}_{7}\left(200 \mathrm{mg}, 3.1 \times 10^{-5} \mathrm{~mol}\right)$ dissoved in $10 \mathrm{~mL}$ of water was added to a solution of $\mathrm{Cu}(\mathrm{en})_{2}\left(\mathrm{NO}_{3}\right)_{2}\left(260 \mathrm{mg}, 8.4 \times 10^{-4} \mathrm{~mol}\right)$ in $10 \mathrm{~mL}$ of water. The solution was stirred for $10 \mathrm{mn}$, filtrated, washed with a large amount of water and dried with ethanol and ether, affording a purple powder (yield : $200 \mathrm{mg}, 84 \%$ ). IR: $v\left(\mathrm{~cm}^{-1}\right)=3407(\mathrm{br}), 3303(\mathrm{~s}), 3250(\mathrm{~s})$, 
3151(s), 2958(m), 2895(m), 1686(m), 1461(w), 1397(w), 1279(w), 1122(sh), 1094(m), 1031(s), 951(sh), 927(s), 868(s), 796(sh), 698(vs), 590(sh), 481(s). Elemental analysis for $\mathrm{Cu}_{6} \mathrm{~W}_{18} \mathrm{Co}_{7} \mathrm{P}_{6} \mathrm{O}_{133} \mathrm{C}_{32} \mathrm{~N}_{24} \mathrm{H}_{176} \mathrm{Na}_{2}$ : (M.W. 7361 g.mol ${ }^{-1}$ ) calcd. (found): W 44.96 (43.00), Co 5.60 (5.52), P 2.52 (2.69), Cu 5.18 (5.18), C 5.22 (5.33), H 2.41 (2.34), N 4.57 (4.92).

$\left.\mathrm{Na}_{2}\left[\mathrm{Cu}(\mathrm{en})_{2}\right)_{6}\right]\left[\left\{\left(\mathrm{PW}_{9} \mathrm{O}_{34}\right) \mathrm{Ni}_{3}(\mathrm{OH})\left(\mathrm{H}_{2} \mathrm{O}\right)_{2}\left(\mathrm{O}_{3} \mathrm{PC}(\mathrm{O})\left(\mathrm{C}_{3} \mathrm{H}_{6} \mathrm{NH}_{3}\right) \mathrm{PO}_{3}\right)\right\}_{2} \mathrm{Ni}\right] \cdot 40 \mathrm{H}_{2} \mathrm{O}\left(\mathrm{Cu}_{6} \mathrm{Ni}_{7}\right)$. Method A: obtention of the $\mathrm{Cu}_{6} \mathrm{Ni}_{7}$ compound as a microcrystalline powder under classical bench conditions. This compound has been synthesized as described above for $\mathbf{C u}_{6} \mathrm{Co}_{7}$ but using $\mathrm{NaKNi}_{7}\left(200 \mathrm{mg}, 3.1 \times 10^{-5} \mathrm{~mol}\right)$ instead of $\mathrm{NaNH}_{4} \mathrm{Co}_{7}$. Yield : $180 \mathrm{mg}, 72 \%$. IR: $v\left(\mathrm{~cm}^{-1}\right)$ $=3407(\mathrm{br}), 3309(\mathrm{~s}), 3261(\mathrm{~s}), 3151(\mathrm{~s}), 2958(\mathrm{~m}), 2895(\mathrm{~m}), 1686(\mathrm{~m}), 1461(\mathrm{w}), 1397(\mathrm{w}), 1279(\mathrm{w})$, 1120(sh), 1094(m), 1035(s), 950(sh), 930(s), 876(s), 789(s), 703(vs), 591(sh), 482(s). Elemental analysis for $\mathrm{Cu}_{6} \mathrm{~W}_{18} \mathrm{Ni}_{7} \mathrm{P}_{6} \mathrm{O}_{128} \mathrm{C}_{32} \mathrm{~N}_{24} \mathrm{H}_{166} \mathrm{Na}_{2}$ (M.W. 7269 g.mol ${ }^{-1}$ ) calcd. (found): W 45.5 (46.1); P 2.56 (2.44); Ni 5.65 (5.69); Cu 5.24 (5.23); C 5.29 (5.83); H 2.30 (2.29); N 4.62 (4.60).

Method $\mathrm{B}$ : obtention of single-crystals of $\mathrm{Cu}_{6} \mathrm{Ni}_{7}$ under hydrothermal conditions. $\mathrm{Na} a_{9}[\mathrm{~A}-$ $\left.\mathrm{PW}_{9} \mathrm{O}_{34}\right] \cdot 7 \mathrm{H}_{2} \mathrm{O}(0.158 \mathrm{~g}, 0.061 \mathrm{mmol})$, alendronic acid $(0.028 \mathrm{~g}, 0.112 \mathrm{mmol})$ and $\mathrm{NiCl}_{2} \cdot 6 \mathrm{H}_{2} \mathrm{O}$ ( $0.040 \mathrm{~g}, 0.168 \mathrm{mmol})$ were suspended in $10 \mathrm{~mL}$ of $0.5 \mathrm{M} \mathrm{CH}_{3} \mathrm{COONH}_{4} / \mathrm{CH}_{3} \mathrm{COOH}(\mathrm{pH} 4.7)$. $\mathrm{Cu}(\mathrm{en})_{2}\left(\mathrm{NO}_{3}\right)_{2}(0.040 \mathrm{~g}, 0.13 \mathrm{mmol})$ was then added to the solution. $2 \mathrm{M}$ sodium hydroxide was added dropwise to $\mathrm{pH}=7.5$. The mixture was sealed in a $23 \mathrm{~cm}^{3}$ Teflon-lined stainless steel reactor before heating to $130{ }^{\circ} \mathrm{C}$ over a period of $1 \mathrm{~h}$, kept at this temperature for $20 \mathrm{~h}$, and cooled to room temperature over a period of $36 \mathrm{~h}$. A mixture of three crystalline phases was collected by filtration. The purple crystals, suitable for diffraction study, were found to be the crystalline form of $\mathrm{Cu}_{6} \mathrm{Ni}_{7}$. 
Infrared Spectra (IR) were recorded on a Nicolet 6700 FT spectrometer. Elemental analyses were performed by the Service Central d'Analyse of CNRS, 69390 Vernaison, France (heavy elements) and by the Service de Microanalyse of CNRS, ICSN, 91198 Gif-sur-Yvette, France $(\mathrm{C}, \mathrm{H}, \mathrm{N})$. For $\mathrm{Cu}_{3} \mathrm{P}_{2} \mathrm{~W}_{18}$, the tungsten/copper, tungsten/phosphor and copper/phosphor ratios were evaluated using a Jeol JSM-5800LV Scanning Microscope equipped with an integrated EDX system.

X-ray Diffraction. Intensity data collection was carried out with a Bruker D8 VENTURE diffractometer equipped with a PHOTON 100 CMOS bidimensional detector using a high brilliance $\mathrm{I} \mu \mathrm{S}$ microfocus X-ray Mo $\mathrm{K} \alpha$ monochromatized radiation $(\lambda=0.71073 \AA)$. The absorption corrections were based on multiple and symmetry-equivalent reflections in the data sets using the SADABS program ${ }^{37}$ based on the method of Blessing. ${ }^{38}$ The structures were solved by direct methods and refined by full-matrix least-squares using the SHELX-TL package. ${ }^{39}$ The hydrogen atoms were theoretically located on the basis of the conformation of the supporting atoms.

2.2 Synthesis of POM/Carbon support (TTFs, rGO or C) composites. The POM (5 mg) and the carbon support $(5 \mathrm{mg})$ in ethanol $(1 \mathrm{~mL})$ were grinded first for $10 \mathrm{~min}$ in a glass bowl and then sonicated for at least $30 \mathrm{~min}$ to form a homogeneous ink. The obtained ink was heated at 60 ${ }^{\circ} \mathrm{C}$ under vacuum for one night and then cooled down to room temperature to obtain the desired composite.

2.3 Electrochemical Measurements. The electrochemical measurements were carried out on an electrochemical bio-potentiostat (CHI 760e, $\mathrm{CH}$ Instrument, Shanghai, China) with a typical three-electrode system. A SCE electrode ( $+0.99 \mathrm{~V}$ vs RHE for basic media, $+0.66 \mathrm{~V}$ vs RHE for neutral medium) was used as the reference electrode, a platinum wire as the counter electrode, 
and the catalysts-modified glassy carbon electrode (GCE) as the working electrode. The working electrodes were prepared by dropping each of the catalyst inks onto a pre-polished GCE. Typically, the catalysts was dispersed into ethanol and sonicated for $30 \mathrm{~min}$ to form a uniform catalyst ink $\left(5 \mathrm{mg} \mathrm{mL}^{-1}\right)$. A total of $7.5 \mu \mathrm{L}$ of the catalyst ink (containing $37.5 \mu \mathrm{g}$ of catalyst) was loaded onto a mirror polished GCE ( $4 \mathrm{~mm}$ in diameter), giving a loading density of $0.3 \mathrm{mg}$ $\mathrm{cm}^{-2}$. After the solvent was evaporated, a thin layer of Nafion solution $(0.5 \mathrm{wt} \%)$ was coated onto the electrode surface. The prepared electrode was dried at room temperature overnight before electrochemical tests. For comparison, GCE coated with $\mathrm{Pt} / \mathrm{C}(20 \mathrm{wt} \% \mathrm{Pt}$ on carbon Vulcan XC-72, purchased from Alfa Aesar) was also fabricated with the same procedure, and the loading density is $60 \mu \mathrm{g} \mathrm{cm}^{-2}$.

[CCDC -151425 contains the supplementary crystallographic data for this paper. These data can be obtained free of charge from The Cambridge Crystallographic Data Centre via www.ccdc.cam.ac.uk/data_request/cif.]

\section{RESULTS AND DISCUSSION}

\section{Synthesis and characterizations of the POMs}

The synthesis of the considered 3d-incorporating POMs is detailed in the experimental section. These POMs all contain a $\mathrm{M}_{7}(\mathrm{M}=\mathrm{Co}$ or $\mathrm{Ni})$ heptanuclear core encapsulated between two $\left[\mathrm{PW}_{9} \mathrm{O}_{34}\right]^{9-}$ units and structured by two alendronate (Ale) ligands, the seven $3 \mathrm{~d}$ centers connecting a total of four exchangeable terminal $\mathrm{H}_{2} \mathrm{O}$ ligands (Figure S1). The already reported water-insoluble cobalt (II) $\mathrm{NH}_{4} \mathrm{Co}_{7}{ }^{35}$ and nickel (II) $\mathrm{NH}_{4} \mathrm{Ni}_{7}{ }^{36}$ POMs have been synthesized under hydrothermal conditions $\left(T=130^{\circ} \mathrm{C}\right)$ in $1 \mathrm{M}$ ammonium acetate solutions $(\mathrm{pH}=7.5)$. The water-soluble salts $\mathrm{NaNH}_{4} \mathrm{Co}_{7}{ }^{26,40}$ and $\mathrm{NaKNi}_{7},{ }^{36}$ which contain the same POM cores than 
$\mathrm{NH}_{4} \mathrm{Co}_{7}$ and $\mathrm{NH}_{4} \mathrm{Ni}_{7}$, respectively, have been synthesized at the same $\mathrm{pH}$ but under classical bench conditions $\left(T=80^{\circ} \mathrm{C}\right)$ and in presence of adapted counter-cations $\left(\mathrm{Na}^{+}\right.$and $\mathrm{NH}_{4}{ }^{+}$for $\mathrm{NaNH}_{4} \mathrm{Co}_{7}$ and $\mathrm{Na}^{+}$and $\mathrm{K}^{+}$for $\left.\mathrm{NaKNi}_{7}\right)$. The metathesis of these cations with $\left[\mathrm{Cu}(\mathrm{en})_{2}\right]^{2+}(\mathrm{en}=$ ethylenediamine) can be easily achieved by adding a solution of $\mathrm{NaNH}_{4} \mathrm{Co}_{7}$ or $\mathrm{NaKNi}_{7}$ to a $\begin{array}{llll}\text { solution of } & {\left[\mathrm{Cu}(\mathrm{en})_{2}\right]^{2+},} & \text { leading }\end{array}$ $\mathrm{Na}_{2}\left[\mathrm{Cu}(\mathrm{en})_{2}\right]_{6}\left[\left\{\left(\mathrm{PW}_{9} \mathrm{O}_{34}\right) \mathrm{Co}_{3}(\mathrm{OH})\left(\mathrm{H}_{2} \mathrm{O}\right)_{2}\left(\mathrm{O}_{3} \mathrm{PC}(\mathrm{O})\left(\mathrm{C}_{3} \mathrm{H}_{6} \mathrm{NH}_{3}\right) \mathrm{PO}_{3}\right)\right\}_{2} \mathrm{Co}\right] \cdot 45 \mathrm{H}_{2} \mathrm{O}\left(\mathrm{Cu}_{6} \mathrm{Co}_{7}\right)$ and $\mathrm{Na}_{2}\left[\mathrm{Cu}(\mathrm{en})_{2}\right]_{6}\left[\left\{\left(\mathrm{PW}_{9} \mathrm{O}_{34}\right) \mathrm{Ni}_{3}(\mathrm{OH})\left(\mathrm{H}_{2} \mathrm{O}\right)_{2}\left(\mathrm{O}_{3} \mathrm{PC}(\mathrm{O})\left(\mathrm{C}_{3} \mathrm{H}_{6} \mathrm{NH}_{3}\right) \mathrm{PO}_{3}\right)\right\}_{2} \mathrm{Ni}\right] \cdot 40 \mathrm{H}_{2} \mathrm{O} \quad\left(\mathrm{Cu}_{6} \mathrm{Ni}_{7}\right)$, respectively, in high yield. Unfortunately, it was not possible to get single-crystals suitable for X-Ray diffraction by recrystallization. A one-pot hydrothermal experiment has thus been performed, starting from $\mathrm{NiCl}_{2},\left[\mathrm{PW}_{9} \mathrm{O}_{34}\right]^{9-}$, alendronic acid and $\left[\mathrm{Cu}(\mathrm{en})_{2}\right]^{2+}$, affording a mixture of powder and crystals. Single-crystal X-Ray diffraction studies (see Table S1) allowed to evidence that the crystalline compound incorporates the $\left\{\left(\mathrm{PW}_{9}\right)_{2} \mathrm{Ni}_{7}(\mathrm{Ale})_{2}\right\} \mathrm{POM}$ described above, with six $\left[\mathrm{Cu}(\mathrm{en})_{2}\right]^{2+}$ and two sodium counter-ions (Figure 1). Four copper units connect the $\left\{\mathrm{Ni}_{7}\right\}$ core via axial Cu-O-P-O-Ni bonds, with shortest $\mathrm{Ni} \cdots \mathrm{Cu}$ distances of $4.85 \AA$, while each of the remaining two is connected to a $\left\{\mathrm{PW}_{9}\right\}$ fragment via $\mathrm{Cu}-\mathrm{O}-\mathrm{W}$ bonds $\left(\mathrm{d}_{\mathrm{Cu} \cdots \mathrm{W}}=3.75\right.$ $\AA$ ). Such composition is in perfect agreement with the elemental analysis of $\mathrm{Cu}_{6} \mathrm{Ni}_{7}$, evidencing that this compound and that obtained via solvothermal treatment possess similar structures. In addition, the IR spectrum of $\mathrm{Cu}_{6} \mathrm{Ni}_{7}$ exhibits both the features of the IR spectra of $\mathrm{NaKNi}_{7}$ and $\left[\mathrm{Cu}(\mathrm{en})_{2}\right]^{2+}$. As expected, elemental analysis and IR spectroscopy indicate that $\mathrm{Cu}_{6} \mathrm{Co}_{7}$ is the cobalt analogue of $\mathrm{Cu}_{6} \mathrm{Ni}_{7}$. Finally, in order to apprehend the role of the $3 \mathrm{~d}$ centers of all these compounds on their ORR activity (see below), the $\mathrm{Cu}_{3} \mathrm{P}_{2} \mathrm{~W}_{18} \mathrm{POM}$ has been synthesized by mixing $\left[\mathrm{Cu}(\mathrm{en})_{2}\right]^{2+}$ and the $\left[\mathrm{P}_{2} \mathrm{~W}_{18} \mathrm{O}_{62}\right]^{6-}$ Dawson-type polyanion. EDX and IR measurements indicate that in $\mathrm{Cu}_{3} \mathrm{P}_{2} \mathrm{~W}_{18},\left[\mathrm{P}_{2} \mathrm{~W}_{18} \mathrm{O}_{62}\right]^{6-}$ is associated to three $\left[\mathrm{Cu}(\mathrm{en})_{2}\right]^{2+}$ cations (Figure $\mathbf{S} 7 \mathrm{a}-\mathrm{c}$ ). 
Once the POMs synthesized, the POM/carbonaceous support composites have been elaborated and characterized.

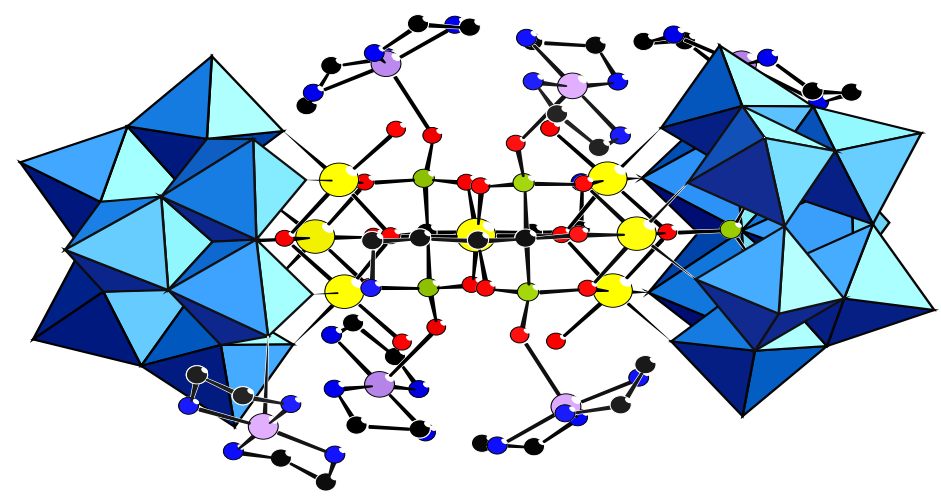

Figure 1. Mixed polyhedral and ball-and-stick representation of $\mathrm{Cu}_{6} \mathrm{Ni}_{7}$; light blue octahedra, $\mathrm{WO}_{6}$; yellow spheres, $\mathrm{Ni}$; green spheres, $\mathrm{P}$; purple spheres, $\mathrm{Cu}$; black spheres, $\mathrm{C}$; dark blue spheres, $\mathrm{N}$; red spheres, O. H atoms have been omitted for clarity.

Physical characterizations of the POM/carbonaceous materials composites 
<smiles>N#Cc1ccc(C#N)cc1</smiles>
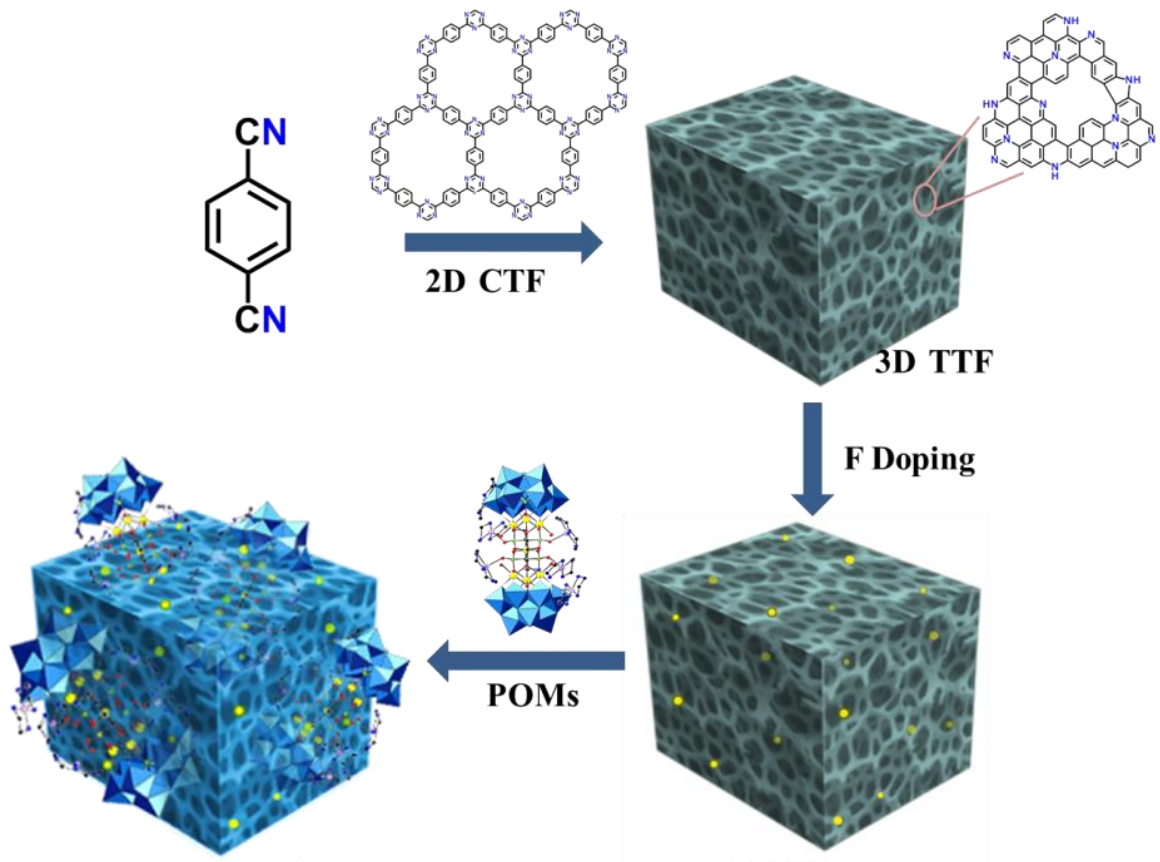

TTF-F

Figure 2. Schematic representation of the synthetic route leading to the POM/TTF-F composites described in this work.

The triazine-based frameworks (see Figure 2) TTF-400, TTF-700, TTF-F ${ }^{32}$ and the reduced graphene oxide rGO used in this work have been prepared as described in the Supplementary Information. $\mathrm{Cu}_{6} \mathrm{Ni}_{7}$ has been finely grinded with these four carbonaceous materials, respectively, affording the $\mathrm{Cu}_{6} \mathrm{Ni}_{7} / \mathrm{TTF}-400, \mathrm{Cu}_{6} \mathrm{Ni}_{7} / \mathrm{TTF}-700, \mathrm{Cu}_{6} \mathrm{Ni}_{7} / \mathrm{TTF}-\mathrm{F}$ and $\mathrm{Cu}_{6} \mathrm{Ni}_{7} / \mathrm{rGO}$ composites. In addition, a composite obtained by mixing carbon Vulcan $\mathrm{XC}-72$ and $\mathrm{Cu}_{6} \mathrm{Ni}_{7}$ $\left(\mathrm{Cu}_{6} \mathrm{Ni}_{7} / \mathrm{C}\right)$ has been prepared. 

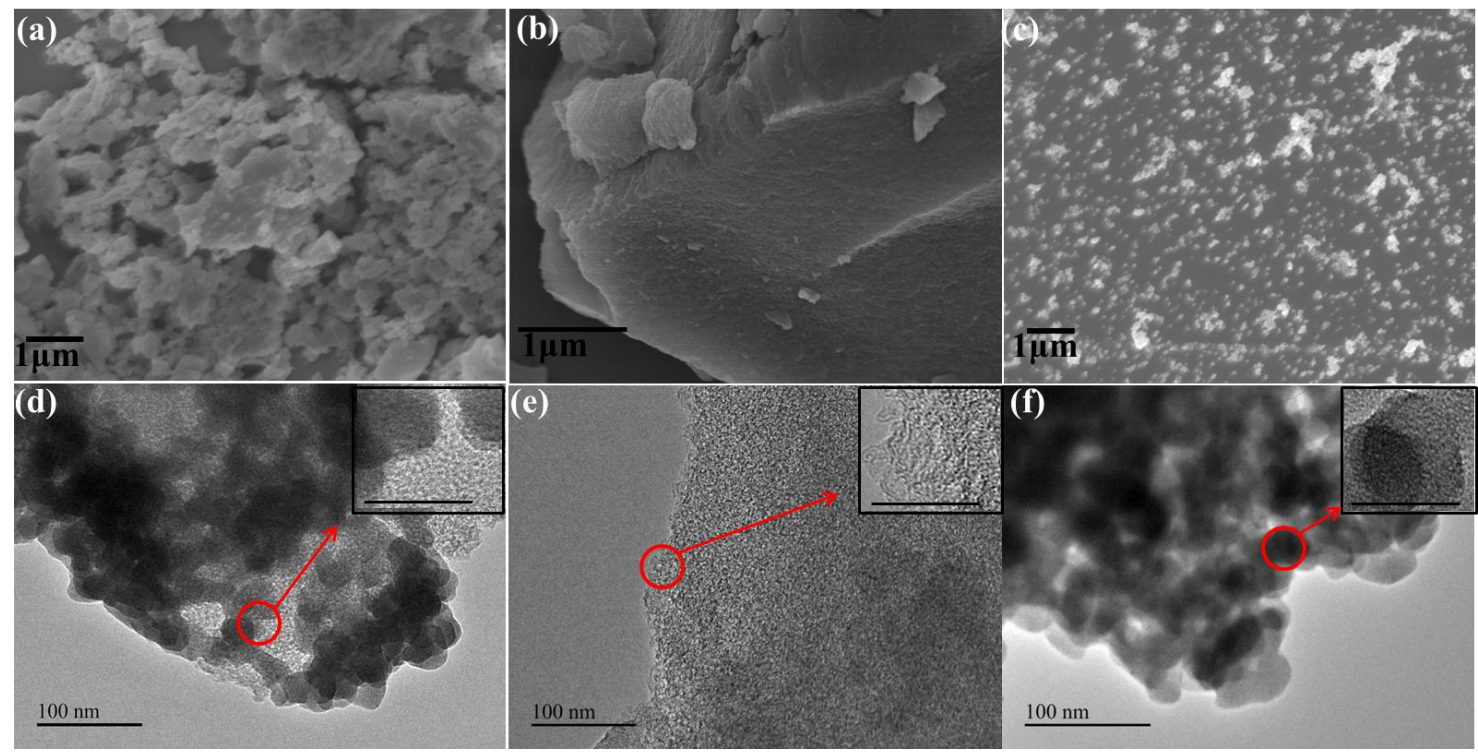

(f)

Figure 3. FESEM images of (a) $\mathrm{Cu}_{6} \mathrm{Ni}_{7} / \mathrm{TTF}-\mathrm{F}$, (b) TTF-F, (c) $\mathbf{C u}_{6} \mathbf{N i}_{7}$; TEM images of (d) $\mathrm{Cu}_{6} \mathrm{Ni}_{7} / \mathrm{TTF}-\mathrm{F}$, (e) TTF-F, (f) $\mathrm{Cu}_{6} \mathrm{Ni}_{7}$ (inset is the corresponding HRTEM images, scale bar, 20 $\mathrm{nm})$.

The $\mathrm{Cu}_{6} \mathrm{Ni}_{7} / \mathrm{TTF}-\mathrm{F}$ composite has been selected for the determination of the POM / triazinebased frameworks structuration. FESEM images show that the $\mathbf{C u}_{\mathbf{6}} \mathbf{N i}_{7}$ nanoclusters are densely attached on the surface of TTF-F (Figure $3 \mathrm{a}-\mathrm{c}$ ). In addition, based on the TEM images in Figure 3 d-f, we found that the coating of $\mathbf{C u}_{\mathbf{6}} \mathbf{N i}_{7}$ on the surface of TTF-F sheets possesses relatively spherical morphology with an average diameter of about 20-40 nm. Notably, the highresolution TEM (HRTEM) images reveal an intimate contact between the POMs and TTF-F (insets in Figure $3 \mathrm{~d}-\mathrm{f}$ ). Furthermore, as presented in the energy-dispersive X-ray spectrum (EDS) elemental mapping images (Figure 4), nitrogen and fluorine are evenly distributed throughout the carbon substrate. In addition, the internal $\mathrm{Cu}, \mathrm{P}, \mathrm{W}$ and $\mathrm{Ni}$ elements (Figure 4c-f) of $\mathbf{C u}_{\mathbf{6}} \mathbf{N i}_{7}$ are evenly distributed in the carbon frameworks. The SEM, TEM and the corresponding EDS elemental mapping images of the $\mathrm{Cu}_{6} \mathrm{Ni}_{7} / \mathrm{rGO}$ and $\mathrm{Cu}_{6} \mathrm{Ni}_{7} / \mathrm{C}$ composite are 
shown in Figure S2-4 and also evidence that these supports have been successfully adsorbed on the $\mathbf{C u}_{\mathbf{6}} \mathbf{N i}_{7}$ with a uniform distribution of the POMs.

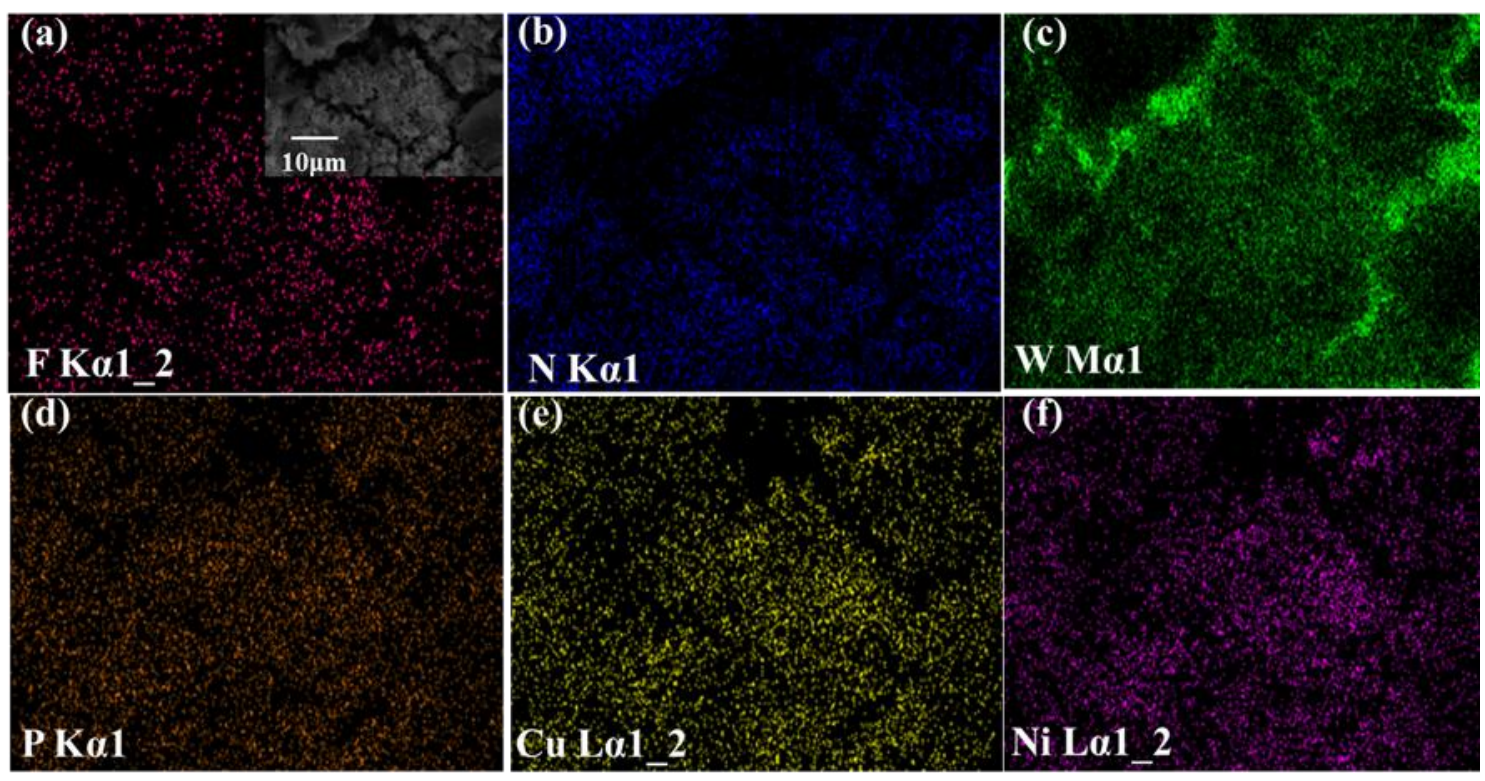

Figure 4. EDS elemental mapping images of (a) $\mathrm{F}$ (inset is the FESEM image of $\mathrm{Cu}_{6} \mathrm{Ni}_{7} / \mathrm{TTF}-\mathrm{F}$, scale bar, $10 \mu \mathrm{m}$ ), (b) N, (c) W, (d) P, (e) Cu and (f) $\mathrm{Ni}_{\text {in }} \mathrm{Cu}_{6} \mathrm{Ni}_{7} / \mathrm{TTF}-\mathrm{F}$.

Raman spectroscopy analysis were performed on all the carbonaceous supports and their related composites incorporating $\mathrm{Cu}_{6} \mathrm{Ni}_{7}$ (Figure S5). All the spectra show D and $\mathrm{G}$ bands at around 1350 and $1594 \mathrm{~cm}^{-1}$, which are assigned to disordered $\mathrm{sp}^{3}$ carbon and graphitic $\mathrm{sp}^{2}$ carbon, respectively. It can be observed that all the pure carbonaceous materials show a relatively weaker D-band compared to the composites, the values of $I_{D} / I_{G}$ increasing with the introduction of $\mathrm{Cu}_{6} \mathrm{Ni}_{7}$. This modification of resonance conditions upon functionalization confirms the interaction of the supports with the POM molecules. 
(a)

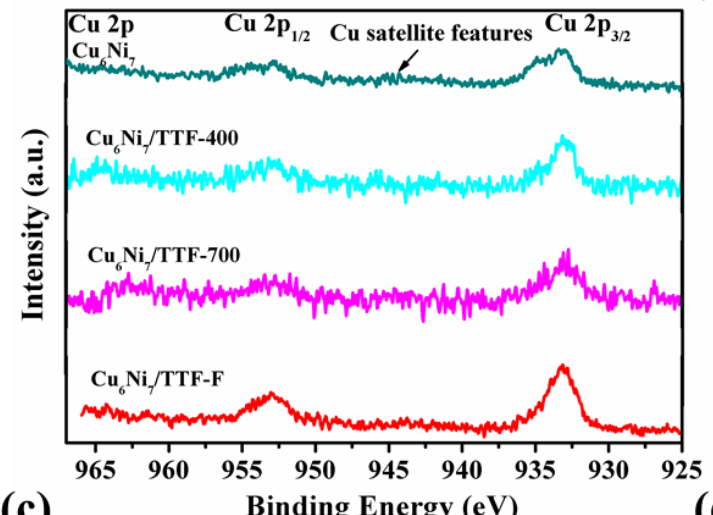

(c)

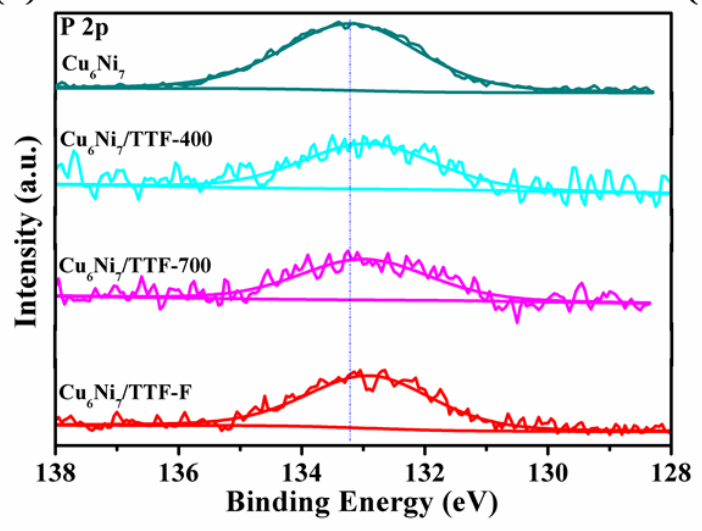

(b)

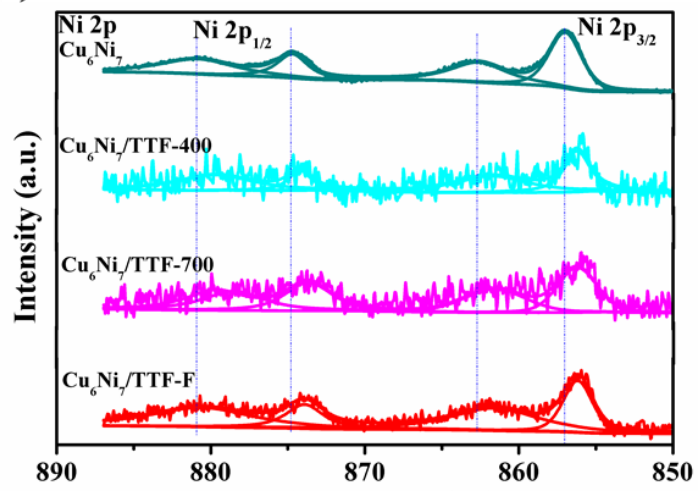

(d)

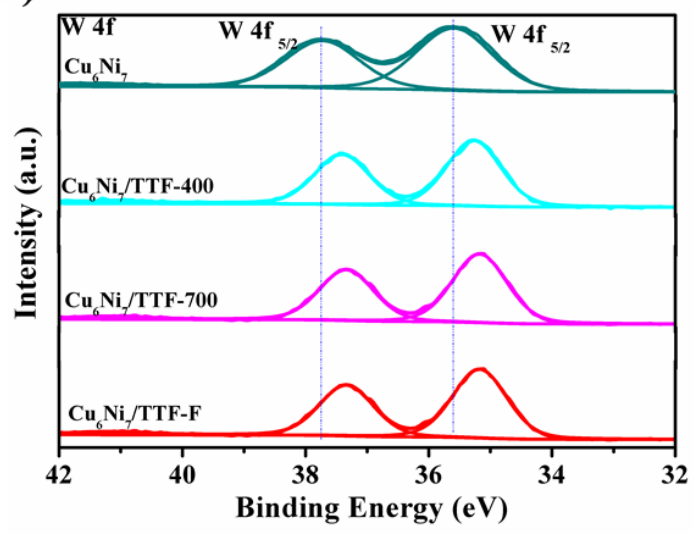

Figure 5. XPS spectra of (a) Cu 2p, (b) Ni 2p, (c) P 2p, and (d) $\mathrm{W} 4 \mathrm{f}$ of $\mathrm{Cu}_{6} \mathrm{Ni}_{7} / \mathrm{TTF}-\mathrm{F}$ compared to those of $\mathrm{Cu}_{6} \mathrm{Ni}_{7} / \mathrm{TTF}-400, \mathrm{Cu}_{6} \mathrm{Ni}_{7} / \mathrm{TTF}-700$ and $\mathrm{Cu}_{6} \mathrm{Ni}_{7}$.

XPS measurements were carried out to confirm the elemental compositions and the valence states of the metallic species in the nanocomposites. Focusing first on the $\mathrm{Cu}_{6} \mathrm{Ni}_{7} / \mathrm{TTF}-\mathrm{F}$ material, its XPS survey spectra show $\mathrm{Cu}, \mathrm{Ni}, \mathrm{P}$ and $\mathrm{W}$ signals, in contrast to those of TTF-F and in line with the presence of $\mathrm{Cu}_{6} \mathrm{Ni}_{7}$ POMs. To be specific, the XPS peaks of $\mathrm{Cu}$ element at 951 957 and $\sim 930-938 \mathrm{eV}$ are assigned to $\mathrm{Cu} 2 \mathrm{p}_{1 / 2}$ and $\mathrm{Cu} 2 \mathrm{p}_{3 / 2}$ respectively (Figure 5a). ${ }^{41-44} \mathrm{~A}$ relative weak $\mathrm{Cu}^{\mathrm{II}}$ satellite peaks at $\sim 940-947$ and $\sim 958-965 \mathrm{eV}$ are also noted. The Ni $2 \mathrm{p}$ XPS spectrum can be deconvoluted into one spin-orbit coupling and two shake-up satellites located at $\sim 862.8 \mathrm{eV}$ and $\sim 880.8 \mathrm{eV}$. The doublet with binding energy at $\sim 856.2 \mathrm{eV}\left(\mathrm{Ni} 2 \mathrm{p}_{3 / 2}\right)$ and 873.8 $\mathrm{eV}\left(\mathrm{Ni} 2 \mathrm{p}_{1 / 2}\right)$ showing energy difference gap of $17.6 \mathrm{eV}$ is assigned to $\mathrm{Ni}^{\mathrm{II}}$ phase (Figure $\mathbf{5 b}$ ). ${ }^{45-47}$ 
The presence of phosphorus is also detected in the hybrids as shown in Figure 5c. For W, there are $\mathrm{W} 4 \mathrm{f}_{5 / 2}$ and $\mathrm{W} 4 \mathrm{f}_{7 / 2}$ doublet with the binding energies of $\sim 37.7$ and $\sim 35.6 \mathrm{eV}$, respectively (Figure 5d), confirming that the tungsten atoms are in their full oxidation states in the deposited $\mathrm{Cu}_{6} \mathrm{Ni}_{7}$. Importantly, it should be noted that all of the $\mathrm{P} 2 \mathrm{p}, \mathrm{W} 4 \mathrm{f}, \mathrm{Cu} 2 \mathrm{p}$, and $\mathrm{Ni} 2 \mathrm{p}$ peaks of $\mathrm{Cu}_{6} \mathrm{Ni}_{7} / \mathrm{TTF}-\mathrm{F}$ are shifted to lower binding energies compared with those of pure $\mathrm{Cu}_{6} \mathrm{Ni}_{7}$. This suggests electron transfer from TTFs to $\mathrm{Cu}_{6} \mathrm{Ni}_{7}$ and confirms the strong interaction between the POM and the support. ${ }^{31}$ The XPS spectra of $\mathrm{Cu}_{6} \mathrm{Ni}_{7} / \mathrm{TTF}-400, \mathrm{Cu}_{6} \mathrm{Ni}_{7} / \mathrm{TTF}-700$ (Figure 5) $\mathrm{Cu}_{6} \mathrm{Ni}_{7} / \mathrm{rGO}$ and $\mathrm{Cu}_{6} \mathrm{Ni}_{7} / \mathrm{C}$ (Figure $\mathbf{S 6}$ e-f) are highly similar to those described for $\mathrm{Cu}_{6} \mathrm{Ni}_{7} / \mathrm{TTF}-$ F.

The interactions between the carbonaceous materials and $\mathrm{Cu}_{6} \mathrm{Ni}_{7}$ can also be evidenced by FTIR analysis (Figure S7d-f). For example, comparing the IR spectra of $\mathrm{Cu}_{6} \mathrm{Ni}_{7}$ and $\mathrm{Cu}_{6} \mathrm{Ni}_{7} / \mathrm{TTF}-\mathrm{F}$, it is observed that the $v_{\text {as }(\mathrm{W}=\mathrm{O})}\left(935 \mathrm{~cm}^{-1}\right.$ in $\mathrm{Cu}_{6} \mathrm{Ni}_{7} ; 937 \mathrm{~cm}^{-1}$ in $\left.\mathrm{Cu}_{6} \mathrm{Ni}_{7} / \mathrm{TTF}-\mathrm{F}\right)$ and $v_{\text {as(W-O-W) }}\left(796\right.$ and $882 \mathrm{~cm}^{-1}$ in $\mathrm{Cu}_{6} \mathrm{Ni}_{7} ; 801$ and $886 \mathrm{~cm}^{-1}$ in $\mathrm{Cu}_{6} \mathrm{Ni}_{7} / \mathrm{TTF}-\mathrm{F}$ ) vibrations are blue-shifted in the composite compared to the pure POM compounds.

\section{Electrocatalysis of the oxygen reduction by the POM/carbonaceous supports composites}

Thanks to their insolubility in most of the useful electrolytes and their chemical compositions, the selected POMs combine several advantages including facile route to the fabrication of stable POM-modified electrodes and the binary combinations of $\mathrm{Cu}$ with $\mathrm{Co}$ or $\mathrm{Ni}$ centers within the POM which should result on effective synergistic electrocatalysis of the ORR. ${ }^{48,49}$ Moreover, the dispersion of the strongly adsorbed POM onto the high-surface-area and conducting supports should boost the POM electrocatalytic activity. ${ }^{50,51}$ In the following, we will focus on the TTF- 
based materials, noting that the intrinsic ORR activities of the TTFs strongly depend on their nature. $^{31}$

The ORR electrocatalytic performances of the various POM-based nanocomposites were evaluated by means of cyclic voltammetry (CV), linear sweep voltammetry (LSV) with a rotating glassy carbon (GC) disk electrode (RDE) or a rotating Pt ring-GC disk (RRDE), and chronoamperometry. The experiments were carried out in oxygen or argon-saturated phosphatebuffered medium $\left(0.2 \mathrm{M} \mathrm{NaH}_{2} \mathrm{PO}_{4}+\mathrm{NaOH}\right)$ at $\mathrm{pH} 7$ or basic medium $(0.1 \mathrm{M} \mathrm{KOH})$. All the potentials are referred to RHE. The ORR onset potential determined from the LSV curve is defined as the potential value at which the current density is $-0.1 \mathrm{~mA} \mathrm{~cm}^{-2}$.

\section{Studies in the neutral medium}

(a)

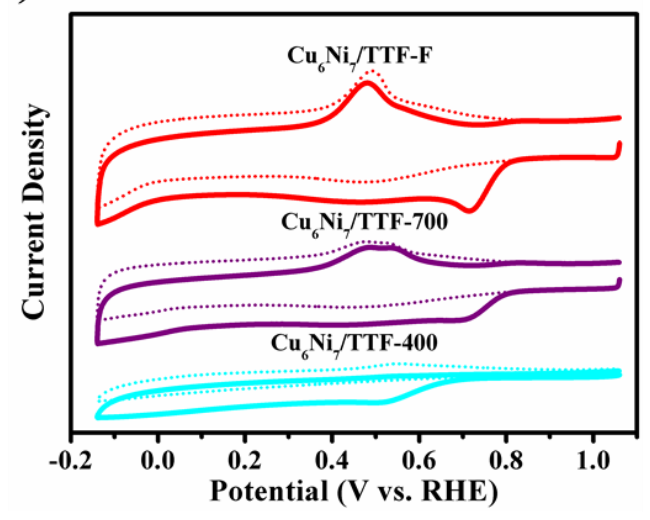

(b)

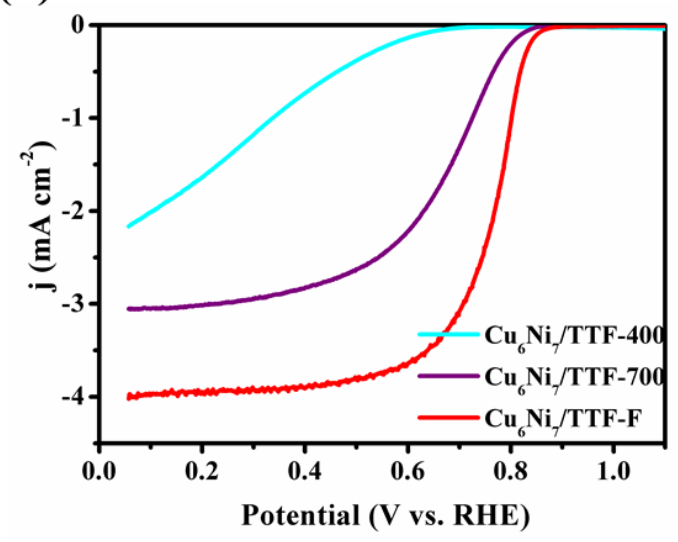

Figure 6. The electrochemical characterization results of $\mathrm{Cu}_{6} \mathrm{Ni}_{7} / \mathrm{TTF}$ in neutral medium: (a) Cyclic voltammograms of $\mathrm{Cu}_{6} \mathrm{Ni}_{7} / \mathrm{TTFs}$ in Ar- (dashed line) and $\mathrm{O}_{2}$-saturated (solid line) $0.2 \mathrm{M}$ $\mathrm{NaH}_{2} \mathrm{PO}_{4} / \mathrm{NaOH}$ solution ( $\mathrm{pH}=7.0$, scanning rate: $10 \mathrm{mV} \mathrm{s}^{-1}$ ); (b) LSV curves of $\mathrm{Cu}_{6} \mathrm{Ni}_{7} / \mathrm{TTFs}$ in $\mathrm{O}_{2}$-saturated $0.2 \mathrm{M} \mathrm{NaH}_{2} \mathrm{PO}_{4} / \mathrm{NaOH}\left(\mathrm{pH}=7.0\right.$, scan rate: $10 \mathrm{mV} \mathrm{s}^{-1}$; rotation rate: $\left.1600 \mathrm{rpm}\right)$. The catalysts loading was $0.3 \mathrm{mg} \mathrm{cm}^{-2}$ for all the electrochemical experiments. 
The CVs of $\mathrm{Cu}_{6} \mathrm{Ni}_{7} / \mathrm{TTF}-\mathrm{F}$ recorded in argon- or oxygen-saturated neutral $\mathrm{pH}$ medium are restricted to the reduction waves of the $\mathrm{Cu}$ centers because those of the $\mathrm{W}$ centers are not involved in the ORR process. Indeed, the reduction waves of the $\mathrm{W}$ centers are located at more negative potential domain and close to the electrolyte discharge (not shown). ${ }^{35}$ As shown in Figure S8a, the $\mathrm{CV}$ pattern of $\mathrm{Cu}_{6} \mathrm{Ni}_{7}$ obtained in the presence of argon is composed by two reduction waves peaking at $+0.480 \mathrm{~V}$ and $+0.350 \mathrm{~V}$ respectively and attributed to the stepwise reduction of $\mathrm{Cu}^{\mathrm{II}}$ centers into $\mathrm{Cu}^{0}$ through $\mathrm{Cu}^{\mathrm{I}}$, in line with previous reports on $\mathrm{Cu}$-containing POMs. ${ }^{52}$ The reoxidation of the resulting $\mathrm{Cu}^{0}$ is featured by two closely spaced waves located at +0.588 and ca. $+0.680 \mathrm{~V}$ respectively. It is worth noting that TTF-F exhibits a broad and illdefined reduction wave peaking at ca. $+0.400 \mathrm{~V}$ (Figure S8b). Figure 6a compares the CV characteristics of $\mathrm{Cu}_{6} \mathrm{Ni}_{7} / \mathrm{TTF}-\mathrm{F}$ observed in the argon- and oxygen-saturated media. In the presence of argon, the broad reduction wave peaking at $+0.482 \mathrm{~V}$ is a combination of the $\mathrm{Cu}$ centers reduction waves and that of TTF-F. In contrast, the characteristics of both re-oxidation waves of $\mathrm{Cu}^{0}$ are not obscured by TTF-F. A well-defined peak observed at $+0.716 \mathrm{~V}$ in the presence of oxygen but not in the argon-saturated electrolyte is attributed to the oxygen reduction peak. The ORR LSV of $\mathrm{Cu}_{6} \mathrm{Ni}_{7} / \mathrm{TTF}-\mathrm{F}$ presented in Figure $6 \mathrm{~b}$ demonstrates that the ORR proceeds through one-step mechanism. As displayed in Figure 6a, the $\mathrm{CVs}$ of $\mathrm{Cu}_{6} \mathrm{Ni}_{7} / \mathrm{TTF}-400$ and $\mathrm{Cu}_{6} \mathrm{Ni}_{7} / \mathrm{TTF}-700$ also feature well-behaved reduction waves in the presence of oxygen. However, the comparison of the $\mathrm{CV}$ characteristics of $\mathrm{Cu}_{6} \mathrm{Ni}_{7} / \mathrm{TTF}-400, \mathrm{Cu}_{6} \mathrm{Ni}_{7} / \mathrm{TTF}-700$ and $\mathrm{Cu}_{6} \mathrm{Ni}_{7} / \mathrm{TTF}-\mathrm{F}$ reveals that their ORR activities are greatly influenced by the carbon support. Indeed, the increase of the thermalized temperature and the doping with fluorine enhance significantly the ORR efficiency as evidenced by the anodic shift of the faradaic current onset potential and the reduction peak potential besides the increase of the reduction current density 
(Figure S9). The LSV measurements featured in Figure $6 \mathrm{~b}$ are in agreement with these observations. The results altogether indicate that the ORR activity increases as follows: $\mathrm{Cu}_{6} \mathrm{Ni}_{7} / \mathrm{TTF}-400<\mathrm{Cu}_{6} \mathrm{Ni}_{7} / \mathrm{TTF}-700<\mathrm{Cu}_{6} \mathrm{Ni}_{7} / \mathrm{TTF}-\mathrm{F}$. Table 1 gathers all the ORR voltammetric characteristics obtained with these three nanocomposites.

Table 1. Summary of ORR catalytic activities of catalysts in neutral medium.

\begin{tabular}{ccccccc}
\hline Catalysts & $\begin{array}{c}E_{\text {onset }} \\
(\mathrm{V} \mathrm{vs.} \mathrm{RHE})\end{array}$ & $\begin{array}{c}E_{\text {halfwave }} \\
(\mathrm{V} \text { vs. RHE })\end{array}$ & $\begin{array}{c}\mathrm{I}_{L} \\
\left(\mathrm{~mA} / \mathrm{cm}^{2}\right)\end{array}$ & $\begin{array}{c}\mathrm{HO}_{2}^{-} \\
0.05 \mathrm{~V} / 0.6 \mathrm{~V}\end{array}$ & $\begin{array}{c}\mathrm{n} \\
0.05 \mathrm{~V} / 0.6 \mathrm{~V}\end{array}$ & $\begin{array}{c}\mathrm{O}_{2} \text { reduction } \\
\text { wave potential } \\
\text { (V vs. RHE })\end{array}$ \\
\hline $\mathrm{Cu}_{6} \mathrm{Ni}_{7} / \mathrm{TTF}-\mathrm{F}$ & 0.854 & 0.768 & 4.02 & $1.5 / 2.9$ & $3.97 / 3.94$ & 0.716 \\
$\mathrm{Cu}_{6} \mathrm{Ni}_{7} / \mathrm{TTF}-700$ & 0.820 & 0.684 & 3.06 & $3.3 / 8.4$ & $3.94 / 3.83$ & 0.680 \\
$\mathrm{Cu}_{6} \mathrm{Ni}_{7} / \mathrm{TTF}-400$ & 0.714 & 0.403 & 2.16 & $4.7 / 60.7$ & $3.90 / 2.78$ & 0.499 \\
$\mathrm{TTF}-\mathrm{F}$ & 0.806 & 0.607 & 3.59 & $2.4 / 13.5$ & $3.95 / 3.73$ & 0.641 \\
$\mathrm{TTF}-700$ & 0.824 & 0.642 & 2.72 & $7.0 / 18.7$ & $3.86 / 3.62$ & 0.636 \\
$\mathrm{TTF}-400$ & 0.597 & 0.320 & 2.07 & $5.3 / 77.1$ & $3.89 / 2.46$ & 0.402 \\
$\mathrm{Cu}_{6} \mathrm{Ni} / \mathrm{rGO}$ & 0.787 & 0.612 & 3.52 & $3.1 / 5.6$ & $3.94 / 3.89$ & 0.607 \\
$\mathrm{Cu}_{6} \mathrm{Ni} / \mathrm{C}$ & 0.677 & 0.470 & 4.79 & $4.9 / 5.0$ & $3.89 / 3.90$ & 0.518 \\
$\mathrm{NH}_{4} \mathrm{Ni}_{7} / \mathrm{TTF}-\mathrm{F}$ & 0.799 & 0.609 & 3.67 & $2.5 / 12.7$ & $3.95 / 3.74$ & 0.641 \\
$\mathrm{Cu}_{6} \mathrm{Co}_{7} / \mathrm{TTF}-\mathrm{F}$ & 0.829 & 0.706 & 4.13 & $1.8 / 6.9$ & $3.96 / 3.86$ & 0.691 \\
$\mathrm{Cu}_{3} \mathrm{P}_{2} \mathrm{~W}_{18} / \mathrm{TTF}-\mathrm{F}$ & 0.824 & 0.686 & 3.64 & $1.6 / 5.0$ & $3.95 / 3.90$ & 0.712 \\
$\mathrm{NH}_{4} \mathrm{Co}_{7} / \mathrm{TTF}-\mathrm{F}$ & 0.838 & 0.663 & 3.35 & $12.0 / 44.3$ & $3.76 / 3.11$ & 0.729 \\
$\mathrm{Pt}_{\mathrm{C}}$ & 0.920 & 0.790 & 3.81 & $7.9 / 5.3$ & $3.84 / 3.89$ & 0.750 \\
\hline
\end{tabular}

$E_{\text {onset: }}$ Onset Potential;

$E_{\text {half-wave }}:$ Half-wave Potential;

$I_{L}$ : Limiting Current Density;

n: Electron Transfer Number.

Another important prerequisite for a viable and effective candidate as ORR electrocatalyst is that the reaction proceeds through a four-electron pathway in order to avoid the formation of significant amount of peroxide as undesirable intermediate product. To evaluate the number of transferred electrons (n) per oxygen molecule during the course of the ORR electrocatalysis by $\mathrm{Cu}_{6} \mathrm{Ni}_{7} / \mathrm{TTF}-\mathrm{F}$-coated GC, the LSV curves were recorded at different rotating speeds from 400 to 1600 rpm. Figure S10a exhibits the dependence of the LSV characteristics on the rotating speed. 
Analysis of the limiting diffusion current densities by the Koutecky-Levich (K-L) plots is featured in Figure S10b. The value of n calculated from the slopes of the K-L plots is about 3.8 over the potential range +0.7 to $0.1 \mathrm{~V}$ which means that the ORR is mainly governed by a fourelectron process. We also performed RRDE tests in order to verify the ORR pathway by monitoring the formation of peroxide species and determine the electron transfer number. As displayed in Figure 7a, the RRDE data confirms this electrocatalytic pathway. Indeed, the measured $\mathrm{HO}_{2}{ }^{-}$yield relative to the total reduction products for $\mathrm{Cu}_{6} \mathrm{Ni}_{7} / \mathrm{TTF}-\mathrm{F}$ is $2.9-1.5 \%$ over the potential range +0.6 to $+0.05 \mathrm{~V}$ and the corresponding electron transfer number is $3.94-3.97$ (Figure 7b), in agreement with the RDE data. For comparison, the RRDE tests were also performed for TTF-F under the same experimental conditions as for $\mathrm{Cu}_{6} \mathrm{Ni}_{7} / \mathrm{TTF}-\mathrm{F}$ and their main ORR characteristics are reported in Table 1. The results show that in the whole potential range (+ 0.6 to $0.05 \mathrm{~V})$ the amounts of peroxide species for $\mathrm{Cu}_{6} \mathrm{Ni}_{7} / \mathrm{TTF}-\mathrm{F}$ are smaller than those observed for TTF-F (13.5-2.4\%) and accordingly, the highest electron transfer number is observed with $\mathrm{Cu}_{6} \mathrm{Ni}_{7} / \mathrm{TTF}-\mathrm{F}$. In addition, the onset and half-wave potentials and the intensity of the limiting ORR current density also underscore the highest performance of $\mathrm{Cu}_{6} \mathrm{Ni}_{7} / \mathrm{TTF}-\mathrm{F}$ with respect to that of TTF-F (Table 1). As shown by the CVs and LSV in Figure S11, $\mathrm{Cu}_{6} \mathrm{Ni}_{7}$ is also active towards the ORR albeit to a lesser extent than both $\mathrm{Cu}_{6} \mathrm{Ni}_{7} / \mathrm{TTF}-\mathrm{F}$ and TTF-F. Indeed, the ORR onset potential observed with $\mathrm{Cu}_{6} \mathrm{Ni}_{7}(+0.178 \mathrm{~V})$ is shifted towards negative potential values by $0.676 \mathrm{~V}$ and $0.628 \mathrm{~V}$ when compared to those of $\mathrm{Cu}_{6} \mathrm{Ni}_{7} / \mathrm{TTF}-\mathrm{F}$ and TTF-F respectively because of poor electrical conductivity of $\mathrm{Cu}_{6} \mathrm{Ni}_{7}$. Therefore, the improved selectivity toward the four electrons reduction of oxygen by $\mathrm{Cu}_{6} \mathrm{Ni}_{7} / \mathrm{TTF}-\mathrm{F}$ is attributed, at least partly, to a synergistic effect of the well-dispersed $\mathrm{Cu}_{6} \mathrm{Ni}_{7}$ on TTF-F and the highly conductive support. For comparison, the $\mathrm{Cu}_{6} \mathrm{Ni}_{7} / \mathrm{rGO}$ and $\mathrm{Cu}_{6} \mathrm{Ni}_{7} / \mathrm{C}$ ORR activities have also been studied. Similarly, 
these composites promote the four-electron ORR electrocatalysis as evidenced by their main ORR characteristics shown in Figure S12 and Figure S13. In the potential range +0.6 to +0.05 $\mathrm{V}$, the measured $\mathrm{HO}_{2}^{-}$yields for $\mathrm{Cu}_{6} \mathrm{Ni}_{7} / \mathrm{rGO}$ and $\mathrm{Cu}_{6} \mathrm{Ni}_{7} / \mathrm{C}$ are 5.6-3.1\% and 5.0-4.9\% respectively and the corresponding electron transfer numbers are 3.89-3.94 and 3.89-3.90 respectively. To our knowledge, $\mathrm{Cu}_{6} \mathrm{Ni}_{7} / \mathrm{TTF}-\mathrm{F}, \mathrm{Cu}_{6} \mathrm{Ni}_{7} / \mathrm{rGO}$ and $\mathrm{Cu}_{6} \mathrm{Ni}_{7} / \mathrm{C}$ are the first examples of POM-based electrocatalysts able to promote one-step reduction of oxygen to water in a neutral medium. Indeed, while we reported the only POM-based ORR electrocatalyst active in neutral medium, this electrocatalysis proceeded via a two-step mechanism and at less favorable potentials than those observed with $\mathrm{Cu}_{6} \mathrm{Ni}_{7} / \mathrm{TTF}-\mathrm{F}, \mathrm{Cu}_{6} \mathrm{Ni} / \mathrm{rGO}$ and $\mathrm{Cu}_{6} \mathrm{Ni}_{7} / \mathrm{C}^{28}$
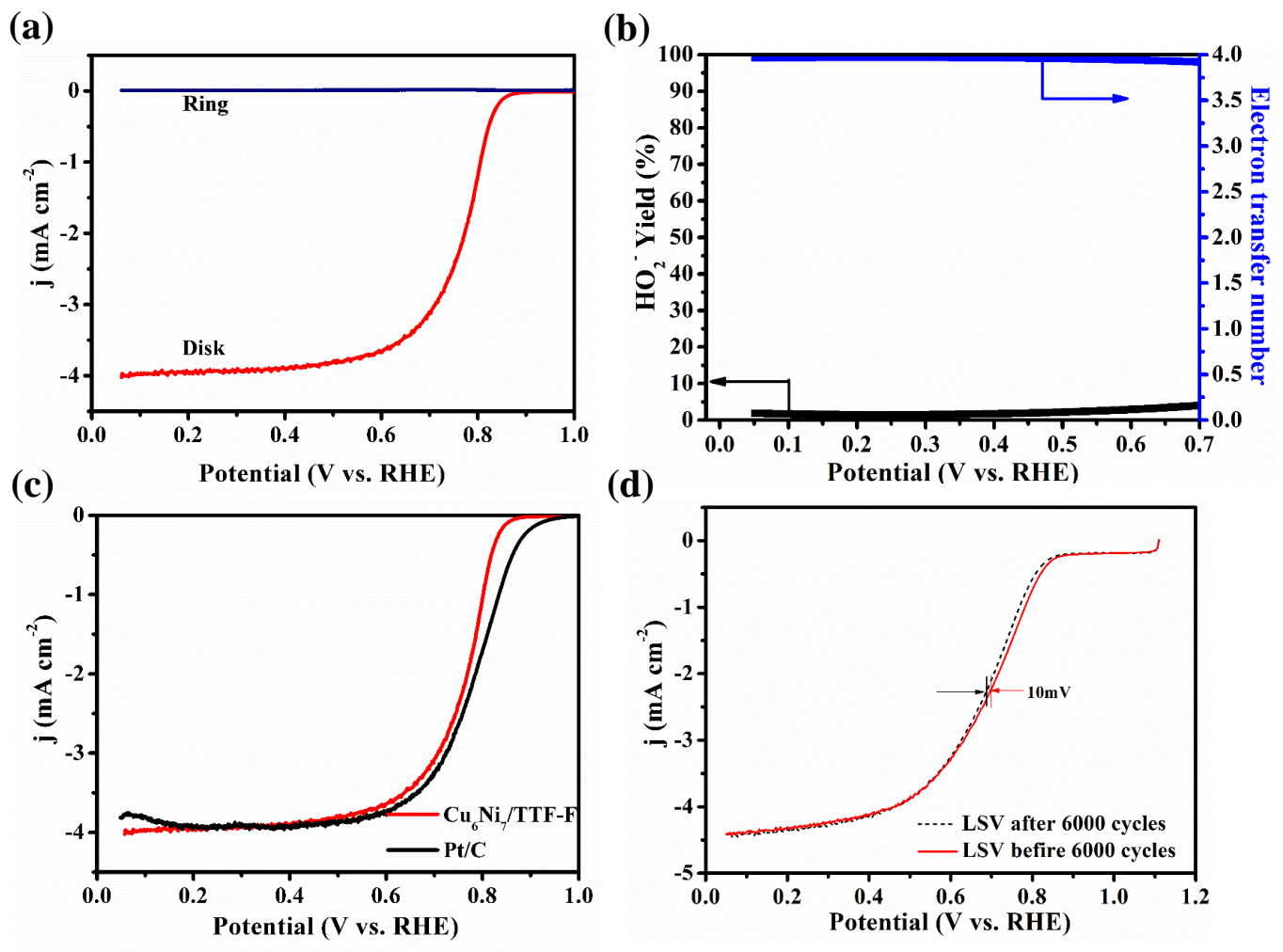

(d)

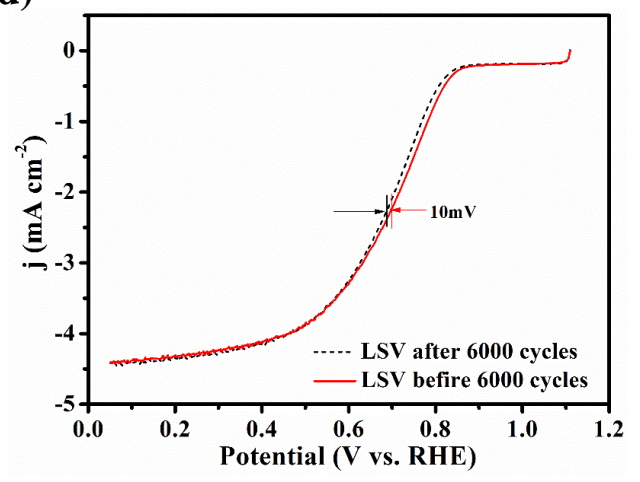

Figure 7. The electrochemical characterization results of $\mathrm{Cu}_{6} \mathrm{Ni}_{7} / \mathrm{TTF}-\mathrm{F}$ in neutral medium: (a)RRDE measurement (1600 rpm) of ORR at $\mathrm{Cu}_{6} \mathrm{Ni} / \mathrm{TTF}-\mathrm{F}$ electrode; (b) variations in $\mathrm{HO}_{2}^{-}$ yield and electron-transfer number at various disk electrode potentials during ORR; (c) LSV 
curves of $\mathrm{Cu}_{6} \mathrm{Ni}_{7} /$ TTF-F compared to Pt/C in $\mathrm{O}_{2}$-saturated $0.2 \mathrm{M} \mathrm{NaH} \mathrm{PO}_{4} / \mathrm{NaOH}$ solution $\left(\mathrm{pH}=7.0\right.$, scan rate: $10 \mathrm{mV} \mathrm{s}^{-1}$; rotation rate: $\left.1600 \mathrm{rpm}\right)$; (d) durability evaluation of $\mathrm{Cu}_{6} \mathrm{Ni}_{7} / \mathrm{TTF}-\mathrm{F}$ before and after 6000 cycles in neutral medium. The catalysts loading is $0.3 \mathrm{mg}$ $\mathrm{cm}^{-2}$ and the loading of $20 \% \mathrm{Pt} / \mathrm{C}$ is $0.06 \mathrm{mg} \mathrm{cm}^{-2}$.

Comparison of the LSV patterns of $\mathrm{Cu}_{6} \mathrm{Ni}_{7} / \mathrm{TTF}-\mathrm{F}$ and $\mathrm{Pt} / \mathrm{C}$ is shown in Figure $7 \mathrm{c}$. Interestingly, the $\mathrm{Cu}_{6} \mathrm{Ni}_{7} / \mathrm{TTF}-\mathrm{F}$ onset potential $(+0.854 \mathrm{~V})$ is shifted towards negative potential values by only $0.066 \mathrm{~V}$ when compared to that of $\mathrm{Pt} / \mathrm{C}$, showing that $\mathrm{Cu}_{6} \mathrm{Ni}_{7} / \mathrm{TTF}-\mathrm{F}$ is able to reduce oxygen at an overpotential close to that of Pt/C. Considering that durability is one of the major concerns in the current fuel cell/battery technology, the $\mathrm{Cu}_{6} \mathrm{Ni}_{7} / \mathrm{TTF}-\mathrm{F}$ catalyst was further subjected to a CV stability test for 6,000 cycles (Figure S14). As Figure 7d shows, LSV curves of $\mathrm{Cu}_{6} \mathrm{Ni}_{7} / \mathrm{TTF}-\mathrm{F}$ show negligible performance loss after the test. There is only a negative shift of $\sim 10 \mathrm{mV}$ in the half-wave potential $\left(E_{1 / 2}\right)$ value at $1600 \mathrm{rpm}$. As shown in Figures S12d and S13d, $\mathrm{Cu}_{6} \mathrm{Ni}_{7} / \mathrm{rGO}$ and $\mathrm{Cu}_{6} \mathrm{Ni}_{7} / \mathrm{C}$ also exhibit high durability during the $40000 \mathrm{~s}$ test but their ORR onset potentials $\left(\mathrm{Cu}_{6} \mathrm{Ni}_{7} / \mathrm{rGO}:+0.787 \mathrm{~V}\right)$ and $\left(\mathrm{Cu}_{6} \mathrm{Ni}_{7} / \mathrm{C}:+0.677 \mathrm{~V}\right)$ reveal that $\mathrm{Cu}_{6} \mathrm{Ni}_{7} / \mathrm{C}$ presents the lowest electrocatalytic activity. The effect of the carbonaceous support on the ORR performances of the nanocomposites (obtained with equal loading amounts of their two components) is also evidenced by comparing their limiting current densities normalized with the same mass. The largest current density $\mathrm{I}$ is observed for $\mathrm{Cu}_{6} \mathrm{Ni}_{7} / \mathrm{TTF}-\mathrm{F}\left(\mathrm{I}\left(\mathrm{Cu}_{6} \mathrm{Ni}_{7} / \mathrm{TTF}-\mathrm{F}\right)=13.4\right.$ $\left.\mathrm{mA} \mathrm{mg}^{-1}>\mathrm{I}\left(\mathrm{Cu}_{6} \mathrm{Ni}_{7} / \mathrm{C}\right)=2.6 \mathrm{~mA} \mathrm{mg}^{-1}>\mathrm{I}\left(\mathrm{Cu}_{6} \mathrm{Ni}_{7} / \mathrm{rGO}\right)=2.0 \mathrm{~mA} \mathrm{mg}^{-1}\right)$ and is mainly attributed to its high specific surface area. ${ }^{32}$ Importantly, the ORR characteristics of $\mathrm{Cu}_{6} \mathrm{Ni}_{7} / \mathrm{TTF}-\mathrm{F}$ compare well with those reported for noble metal-free ORR electrocatalysts in neutral media (Table 2). 
Altogether, the observations suggest that $\mathrm{Cu}_{6} \mathrm{Ni}_{7} / \mathrm{TTF}-\mathrm{F}$ is potentially an attractive alternative to Pt-based ORR electrocatalysts.

Table 2. Comparison of the performances between $\mathrm{Cu}_{6} \mathrm{Ni}_{7} / \mathrm{TTF}-\mathrm{F}$ (this work) and other catalysts catalyzing ORR in neutral media reported in the literatures.

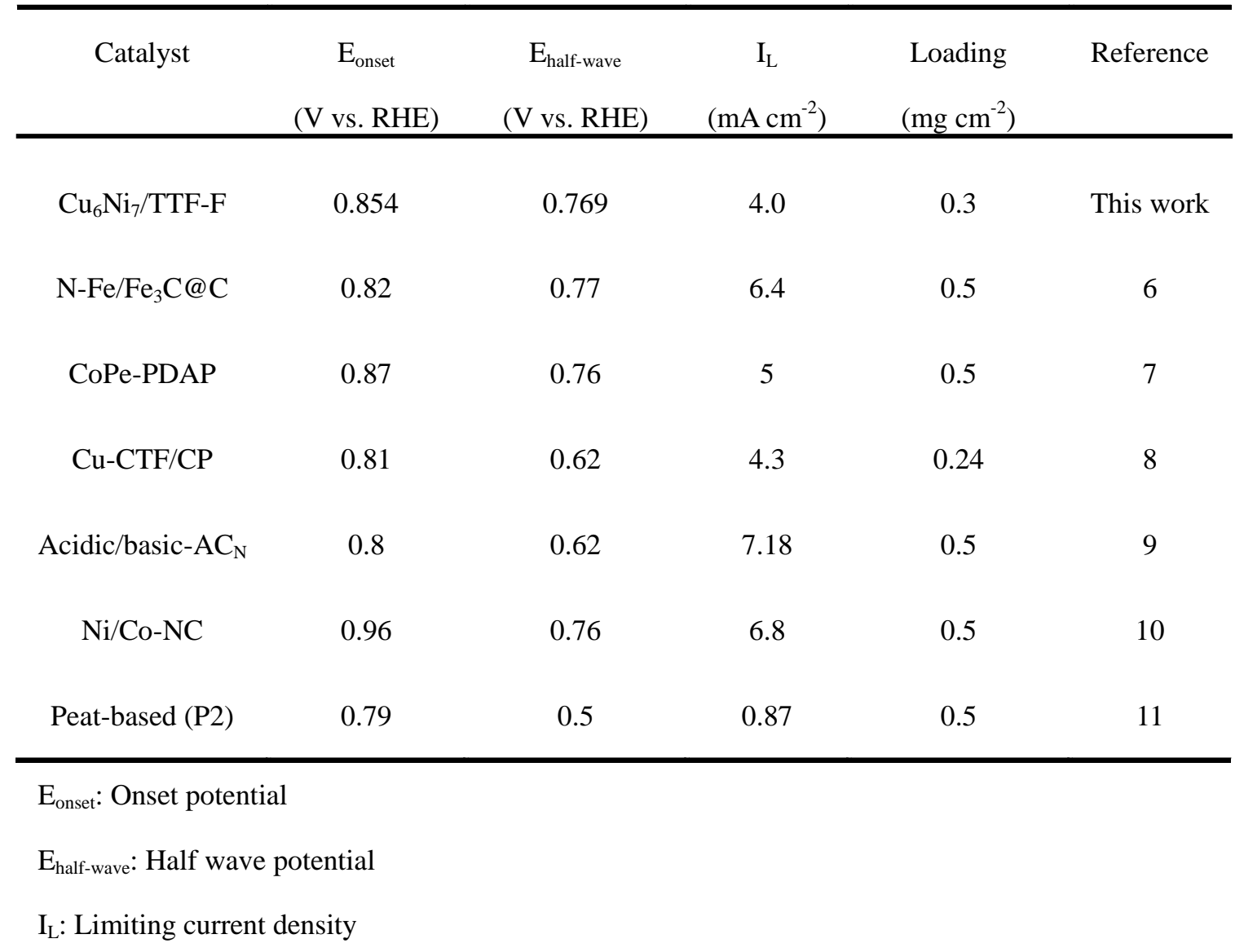

Studies in the basic medium 

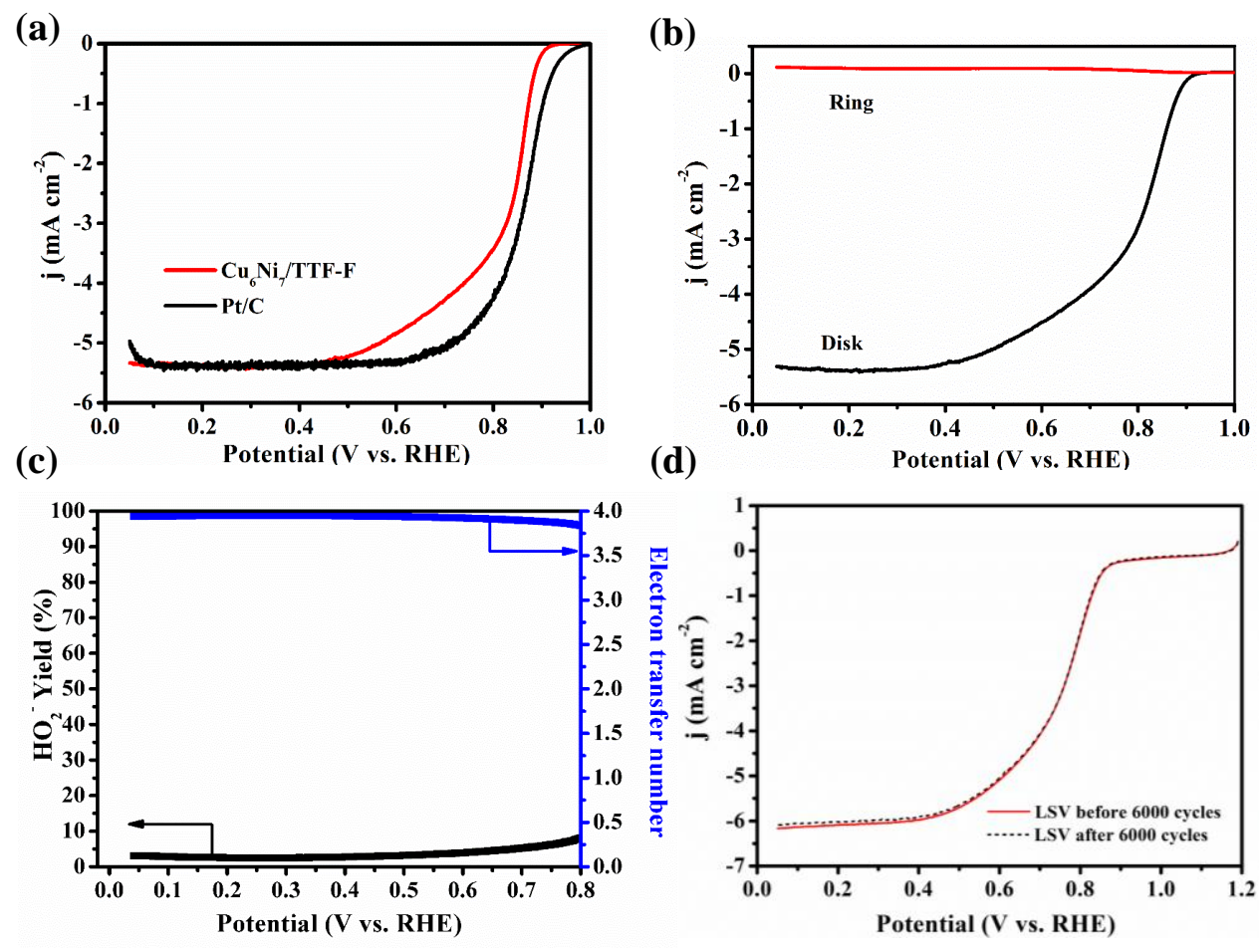

Figure 8. The electrochemical characterization results of $\mathrm{Cu}_{6} \mathrm{Ni}_{7} / \mathrm{TTFs}$ in basic medium. (a) LSV curves of $\mathrm{Cu}_{6} \mathrm{Ni}_{7} / \mathrm{TTF}$ and $\mathrm{Pt} / \mathrm{C}$ in $\mathrm{Ar}$ - and $\mathrm{O}_{2}$-saturated $0.1 \mathrm{M} \mathrm{KOH}$ solution (scanning rate: 10 $\mathrm{mV} \mathrm{s}^{-1}$, rotation rate: $1600 \mathrm{rpm}$ ); (b) RRDE measurement (1600 rpm) of ORR at $\mathrm{Cu}_{6} \mathrm{Ni}_{7} / \mathrm{TTF}-\mathrm{F}$ electrode; (c) $\mathrm{HO}_{2}^{-}$yields obtained through the rotating ring-disk electrode (RRDE) measurements; (d) the stability of $\mathrm{Cu}_{6} \mathrm{Ni}_{7} / \mathrm{TTF}-\mathrm{F}$ before and after 6000 cycles in $\mathrm{O}_{2}$-saturated 0.1 $\mathrm{M} \mathrm{KOH}$ solution. The catalysts loading is $0.3 \mathrm{mg} \mathrm{cm}^{-2}$ and the loading of $20 \% \mathrm{Pt} / \mathrm{C}$ is $0.060 \mathrm{mg}$ $\mathrm{cm}^{-2}$.

The $\mathrm{Cu}_{6} \mathrm{Ni}_{7} / \mathrm{TTF}-\mathrm{F}$ cathode also functioned as highly active ORR electrocatalyst in basic medium. The CV and LSV characteristics shown in Figure S15 and Table S2 reveal that the ORR activity in basic medium increases in the same order than in the neutral medium $\left(\mathrm{Cu}_{6} \mathrm{Ni}_{7} / \mathrm{TTF}-400<\mathrm{Cu}_{6} \mathrm{Ni}_{7} / \mathrm{TTF}-700<\mathrm{Cu}_{6} \mathrm{Ni}_{7} / \mathrm{TTF}-\mathrm{F}\right)$. The CV characteristics of $\mathrm{Cu}_{6} \mathrm{Ni}_{7} / \mathrm{TTF}-\mathrm{F}$ recorded in argon- or oxygen-saturation conditions show that the ORR is featured by a welldefined reduction wave peaking at $+0.806 \mathrm{~V}$ (Figure S15a). The dependence of the LSV 
characteristics on the rotating speed and the K-L plots for $\mathrm{Cu}_{6} \mathrm{Ni}_{7} / \mathrm{TTF}-\mathrm{F}$ is displayed in Figure S15 c and S15 d respectively. From the slopes of the K-L plots, the value of electron transfer number was calculated to be about 3.8 over the potential range $+0.8-0.1 \mathrm{~V}$ which indicates that the ORR is mainly governed by a four-electron process. Figure $\mathbf{8 b}$ shows the ORR polarization curves recorded at $1600 \mathrm{rpm}$ for $\mathrm{Cu}_{6} \mathrm{Ni}_{7} / \mathrm{TTF}-\mathrm{F}$ in $0.1 \mathrm{M} \mathrm{KOH}$ solution, along with the respective ring current values relative to the oxidation of hydrogen peroxide ions $\left(\mathrm{HO}_{2}{ }^{-}\right)$measured at the Pt-ring electrode held at a potential of $0.50 \mathrm{~V}$. The RRDE data exhibited in Figure $8 \mathrm{c}$ confirm this electrocatalytic pathway. Indeed, the measured $\mathrm{HO}_{2}^{-}$yield relative to the total reduction products for $\mathrm{Cu}_{6} \mathrm{Ni}_{7} / \mathrm{TTF}-\mathrm{F}$ was $3.9-3.1 \%$ over the potential range +0.6 to $+0.05 \mathrm{~V}$ and the corresponding electron transfer number was 3.92-3.94. The amount of peroxide species measured with $\mathrm{Cu}_{6} \mathrm{Ni}_{7} / \mathrm{TTF}-\mathrm{F}$ is about 4 smaller than that obtained with TTF-F. Moreover, the CV and LSV characteristics featured in Figure S16 indicate that $\mathrm{Cu}_{6} \mathrm{Ni}_{7}$ is an active ORR electrocatalyst in the basic medium, but, as for the neutral medium, its ORR onset potential (+ $0.550 \mathrm{~V}$ ) is shifted towards negative potential values by $0.356 \mathrm{~V}$ and $0.303 \mathrm{~V}$ when compared to those of $\mathrm{Cu}_{6} \mathrm{Ni}_{7} / \mathrm{TTF}-\mathrm{F}$ and TTF-F respectively In line with the results obtained in the neutral medium, the ORR performance of $\mathrm{Cu}_{6} \mathrm{Ni}_{7} / \mathrm{TTF}-\mathrm{F}$ is, here again, attributed to the synergy between its two components. The great beneficial effect of $\mathrm{Cu}_{6} \mathrm{Ni}_{7}$ induces strikingly low amount of $\mathrm{HO}_{2}{ }^{-}$for $\mathrm{Cu}_{6} \mathrm{Ni}_{7} / \mathrm{TTF}-\mathrm{F}$ (3.1\%) with respect to those observed for TTF-F in the present work $(13.3 \%)$ at $+0.05 \mathrm{~V}$ or in a recent report $(15 \%) .{ }^{32}$ The ORR data displayed in Table S2 indicate that $\mathrm{Cu}_{6} \mathrm{Ni}_{7} / \mathrm{C}$ can also promote four-electron ORR electrocatalysis, albeit to a lesser extent than both $\mathrm{Cu}_{6} \mathrm{Ni}_{7} / \mathrm{TTF}-\mathrm{F}$ and $\mathrm{Cu}_{6} \mathrm{Ni}_{7} / \mathrm{rGO}$. As shown in Table $\mathbf{S} 2$ the characteristics of the ORR LSVs of $\mathrm{Cu}_{6} \mathrm{Ni}_{7} / \mathrm{rGO}$ and $\mathrm{Pt} / \mathrm{C}$ are close, the ORR onset potential of $\mathrm{Cu}_{6} \mathrm{Ni}_{7} / \mathrm{rGO}(+0.93 \mathrm{~V}$ ) being only slightly negative (by $0.03 \mathrm{~V}$ ) compared to that of Pt/C. Figure 8a shows that the ORR onset 
potential obtained with $\mathrm{Cu}_{6} \mathrm{Ni}_{7} / \mathrm{TTF}-\mathrm{F}(+0.906 \mathrm{~V})$ and that observed for $\mathrm{Pt} / \mathrm{C}(+0.96 \mathrm{~V})$ are also close. Moreover, the durability of $\mathrm{Cu}_{6} \mathrm{Ni}_{7} / \mathrm{TTF}-\mathrm{F}$ is excellent. The stability of $\mathrm{Cu}_{6} \mathrm{Ni}_{7} / \mathrm{TTF}-\mathrm{F}$ was assessed by cycling the catalyst between $0.05 \mathrm{~V}$ and $1.2 \mathrm{~V}$ vs. RHE at $200 \mathrm{mV} \mathrm{s}^{-1}$ (Figure S17). After 6000 continuous cycles, the $\mathrm{Cu}_{6} \mathrm{Ni}_{7} / \mathrm{TTF}-\mathrm{F}$ modified electrode show negligible shift in both $E_{1 / 2}$ and limiting current density (Figure 8d). The nano-composites $\mathrm{Cu}_{6} \mathrm{Ni}_{7} / \mathrm{rGO}$ and $\mathrm{Cu}_{6} \mathrm{Ni}_{7} / \mathrm{C}$ also present excellent durability. However, the limiting current density normalized by the same mass obtained with $\mathrm{Cu}_{6} \mathrm{Ni}_{7} / \mathrm{TTF}-\mathrm{F}\left(17.69 \mathrm{~mA} \mathrm{mg}^{-1}\right.$ ) is by far larger than those of $\mathrm{Cu}_{6} \mathrm{Ni}_{7} / \mathrm{rGO}$ $\left(2.92 \mathrm{~mA} \mathrm{mg}^{-1}\right)$ and $\mathrm{Cu}_{6} \mathrm{Ni}_{7} / \mathrm{C}\left(2.02 \mathrm{~mA} \mathrm{mg}^{-1}\right)$. Altogether, these observations underscore the high ORR performance of $\mathrm{Cu}_{6} \mathrm{Ni}_{7} / \mathrm{TTF}-\mathrm{F}$. To our knowledge, $\mathrm{Cu}_{6} \mathrm{Ni}_{7} / \mathrm{TTF}-\mathrm{F}$ represents the first example of POM based noble metal-free ORR electrocatalyst possessing such high ORR electrocatalytic activity in a basic medium.

\section{Effect of the chemical composition of the POM}


(a)

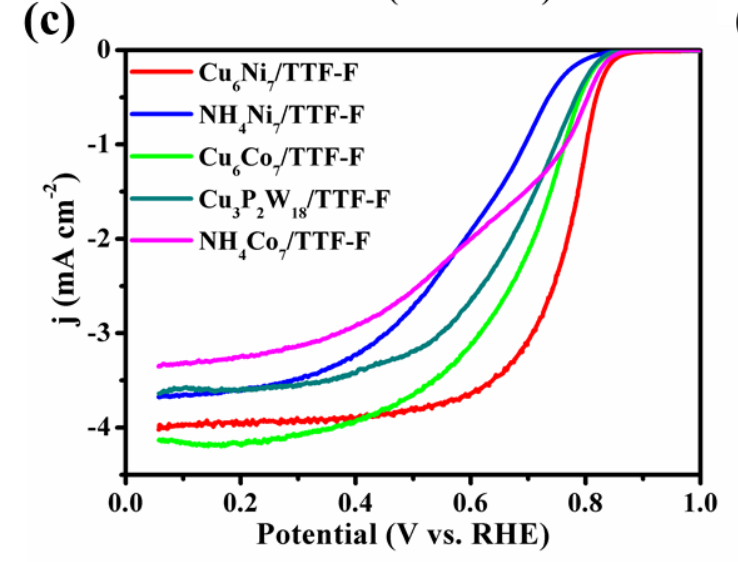

(b)

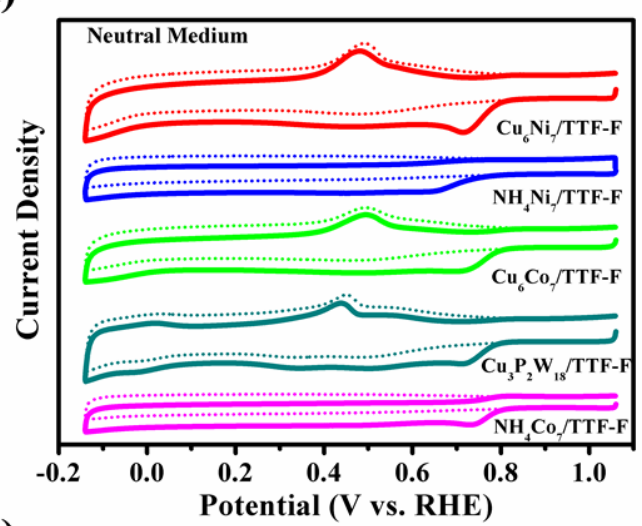

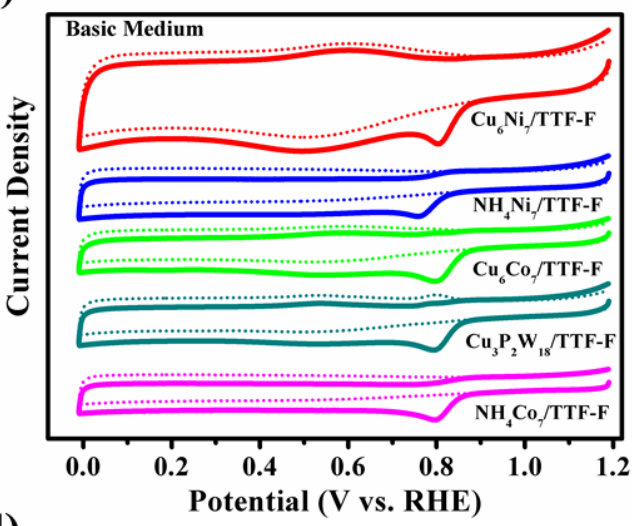

(d)

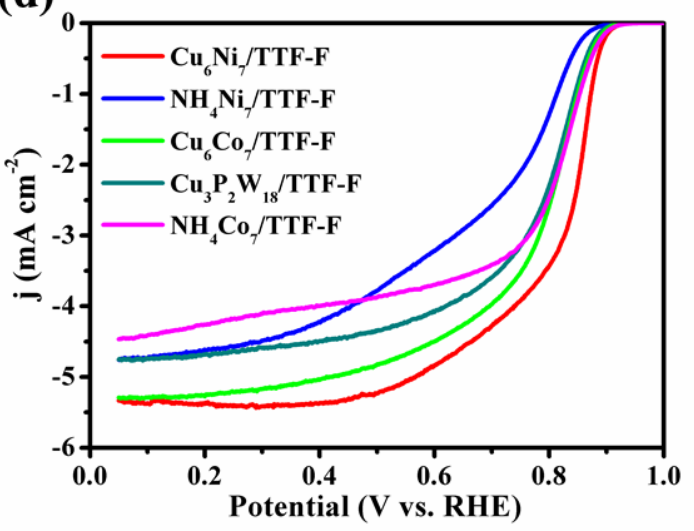

Figure 9. The electrochemical characterization results of various POM/TTF-F in neutral and basic medium. $\mathrm{CV}$ curves of POM/TTF-F in $\mathrm{O}_{2}$ - (full lines) and Ar-saturated (dotted lines) 0.2 $\mathrm{M} \mathrm{NaH} 2 \mathrm{PO}_{4} / \mathrm{NaOH}$ (a) and $0.1 \mathrm{M} \mathrm{KOH}$ solution (b) (scan rate: $10 \mathrm{mV} \mathrm{s}^{-1}$; rotation rate: 1600 rpm); LSV curves of POM/TTF-F in $\mathrm{O}_{2}$-saturated $0.2 \mathrm{M} \mathrm{NaH}_{2} \mathrm{PO}_{4} / \mathrm{NaOH}$ (c) and $0.1 \mathrm{M} \mathrm{KOH}$ (d) (scanning rate: $10 \mathrm{mV} \mathrm{s}^{-1}$, rotation rate: $1600 \mathrm{rpm}$ ). The catalysts loading is $0.3 \mathrm{mg} \mathrm{cm}^{-2}$ for all the electrochemical experiments.

The ORR activities of $\mathrm{Cu}_{6} \mathrm{Ni}_{7} / \mathrm{TTF}-\mathrm{F}$ in the neutral and basic media were further compared to those of $\mathrm{Cu}_{6} \mathrm{Co}_{7} / \mathrm{TTF}-\mathrm{F}, \mathrm{Cu}_{3} \mathrm{P}_{2} \mathrm{~W}_{18} / \mathrm{TTF}-\mathrm{F}, \mathrm{NH}_{4} \mathrm{Ni}_{7} / \mathrm{TTF}-\mathrm{F}$ and $\mathrm{NH}_{4} \mathrm{Co}_{7} / \mathrm{TTF}-\mathrm{F}$ in order to get insight into the influence of the POM-inserted $3 \mathrm{~d}$ metal and that of the POM counter-ion. Figure 9a and 9b display superimposed $\mathrm{CVs}$ recorded in Ar- or $\mathrm{O}_{2}$-saturated basic and neutral electrolytes, respectively, for all the selected POM/TTF-F assemblies. As found for $\mathrm{Cu}_{6} \mathrm{Ni}_{7} / \mathrm{TTF}-$ 
$\mathrm{F}$, the comparison of the $\mathrm{CV}$ characteristics obtained in argon and dioxygen indicates unambiguously that all these hybrids are active towards the ORR. Moreover, either in neutral or basic media, the ORR CV and LSV characteristics depend on the $3 \mathrm{~d}$ metal centers incorporated into the POM and that of the counter-ions as evidenced by the onset potentials (Figure $9 \mathrm{c}$ and 9 d), the ORR reduction peak potentials and the current densities (Table 1 and S2). The RRDE data also indicate that the ORR electron transfer number and the measured $\mathrm{HO}_{2}{ }^{-}$yield vary with respect to the POM. As shown in Figure S18, a significant drops of the $\mathrm{HO}_{2}^{-}$yields are observed for $\mathrm{Cu}_{3} \mathrm{P}_{2} \mathrm{~W}_{18}$ /TTF-F (basic medium: 10-14\%, neutral medium: $\sim 2-5 \%$ ) and $\mathrm{NH}_{4} \mathrm{Ni}_{7} / \mathrm{TTF}-\mathrm{F}$ (basic medium: 5-13\%, neutral medium: 2-13\%) compared to $\mathrm{NH}_{4} \mathrm{Co}_{7} / \mathrm{TTF}-\mathrm{F}$ (basic medium: 20-27\%, neutral medium: 12-44\%) (Table 1 and S2); and the corresponding electron transfer numbers of $\mathrm{Cu}_{3} \mathrm{P}_{2} \mathrm{~W}_{18} / \mathrm{TTF}-\mathrm{F}$ and $\mathrm{NH}_{4} \mathrm{Ni}_{7} / \mathrm{TTF}-\mathrm{F}$ are higher than that of $\mathrm{NH}_{4} \mathrm{Co}_{7} / \mathrm{TTF}-\mathrm{F}$. This indicates that the $\mathrm{Cu}-\mathrm{POM}$ and Ni-POM have better four-electron selectivity compared to CoPOM. Moreover, the average $\mathrm{HO}_{2}^{-}$yield of $\mathrm{Cu}_{6} \mathrm{Ni}_{7} / \mathrm{TTF}-\mathrm{F}$ and $\mathrm{Cu}_{6} \mathrm{Co}_{7} / \mathrm{TTF}-\mathrm{F}$ in neutral medium are $\sim 3.5 \%$ and $\sim 10 \%$ respectively, corresponding to average electron transfer number of 3.9 and 3.8. This again suggests that Ni plays a better role than Co in enhancing catalytic selectivity than Co. But overall, our results clearly show that $\mathrm{Cu}$ and $\mathrm{Ni}$ causes a remarkable synergistic effect, leading to the best catalytic activity for ORR.

First, the presence of $3 \mathrm{~d}$ centers into the POM core increases the performance of the reported system as evidenced by the comparison of the activities of the $\mathrm{Cu}_{6} \mathrm{Ni}_{7} / \mathrm{TTF}-\mathrm{F}, \mathrm{Cu}_{6} \mathrm{Co}_{7} / \mathrm{TTF}-\mathrm{F}$ and $\mathrm{Cu}_{3} \mathrm{P}_{2} \mathrm{~W}_{18} / \mathrm{TTF}-\mathrm{F}$. Second, comparing the activities of both i) $\mathrm{Cu}_{6} \mathrm{Ni}_{7} / \mathrm{TTF}-\mathrm{F}$ and $\mathrm{Cu}_{6} \mathrm{Co}_{7} / \mathrm{TTF}-\mathrm{F}$ and ii) $\mathrm{NH}_{4} \mathrm{Ni}_{7} / \mathrm{TTF}-\mathrm{F}$ and $\mathrm{NH}_{4} \mathrm{Co}_{7} / \mathrm{TTF}-\mathrm{F}$, it is observed that the presence of nickel clearly enhances the ORR activity of the composite compared to the presence of cobalt. As an example, we can underline that the ORR activity of $\mathrm{NH}_{4} \mathrm{Ni}_{7} / \mathrm{TTF}-\mathrm{F}$ is higher than that of $\mathrm{NH}_{4} \mathrm{Co}_{7} / \mathrm{TTF}-\mathrm{F}$ 
in the whole potential range +0.6 to $+0.05 \mathrm{~V}$ and the yield of $\mathrm{HO}_{2}{ }^{-}$at $+0.05 \mathrm{~V}$ for $\mathrm{NH}_{4} \mathrm{Ni}_{7} / \mathrm{TTF}-$ $\mathrm{F}$ is about 4.7 times lower than that of $\mathrm{NH}_{4} \mathrm{Co}_{7} / \mathrm{TTF}-\mathrm{F}$ in both neutral and basic media which underscores the beneficial effect of the $\mathrm{Ni}^{\mathrm{II}}$ centers on the selectivity towards the four-electron reduction of $\mathrm{O}_{2}$. Third, comparing the behaviors of $\mathrm{Cu}_{6} \mathrm{Ni}_{7} / \mathrm{TTF}-\mathrm{F}$ and $\mathrm{NH}_{4} \mathrm{Ni}_{7} / \mathrm{TTF}-\mathrm{F}$, it can be deduced that the use of the simple coordination complexes $\left[\mathrm{Cu}(\mathrm{en})_{2}\right]^{2+}$ as counterions instead of the classical $\mathrm{NH}_{4}{ }^{+}$cations drastically improve the ORR activity of such composite. As reported for various bimetallic ORR catalysts, ${ }^{45-47}$ it can be proposed that the co-existence of $\mathrm{Ni}$ and $\mathrm{Cu}$ centers within $\mathrm{Cu}_{6} \mathrm{Ni}_{7} / \mathrm{TTF}-\mathrm{F}$ leads to higher catalytic ORR activity than those of $\mathrm{NH}_{4} \mathrm{Ni}_{7} / \mathrm{TTF}-\mathrm{F}$ or $\mathrm{Cu}_{3} \mathrm{P}_{2} \mathrm{~W}_{18} / \mathrm{TTF}-\mathrm{F}$ due to the beneficial synergistic cooperation of two different metal centers.

Based on the discussion above and density functional theory (DFT) calculations, a possible mechanism for the synergistic catalytic activity can be proposed (Figure S19). Comparing the behaviors of POM/TTF-F, POM and TTF-F, it can be deduced that pure POMs can hardly catalyze ORR owing to their poor conductivity and small surface area (Figure S20). The $\mathrm{N}_{2}$ sorption experiments (Figure S21) and Table S3 show that the BET surface area of TTF increases from 1175 to $2237 \mathrm{~m}^{2} \mathrm{~g}^{-1}$ with increasing the pyrolysis temperature from 400 to 700 ${ }^{\circ} \mathrm{C}$, much higher than that of $\mathrm{C}$ and $\mathrm{rGO}$. The surface area of TTF-F further expanded to $2503 \mathrm{~m}^{2}$ $\mathrm{g}^{-1}$ with the doping of $\mathrm{F}$, leading to the highest pore volume $\left(1.88 \mathrm{~cm}^{3} \mathrm{~g}^{-1}\right)$ and size $(3 \mathrm{~nm})$. The high specific surface areas, positive charge (caused by electron transfer) and porous structures of TTF-F enable easy accessibility of the active sites to the dissolved $\mathrm{O}_{2}$, as well as provide efficient pathways for mass transport and improve the electrical conductivity, facilitating the ORR.

Comparing the activities of $\mathrm{Cu}_{3} \mathrm{P}_{2} \mathrm{~W}_{18}$ /TTF-F, $\mathrm{NH}_{4} \mathrm{Ni}_{7} / \mathrm{TTF}-\mathrm{F}$ and $\mathrm{NH}_{4} \mathrm{Co}_{7} / \mathrm{TTF}-\mathrm{F}$, it is observed that $\mathrm{Cu}$ enhances the ORR activity of the composite more distinctly than $\mathrm{Ni}$ and $\mathrm{Co}$. 
Connecting $\mathrm{Cu}$ with $\mathrm{Co}$ or $\mathrm{Ni}$ atoms could modify the electronic structure of $\mathrm{Cu}$ by the so-called electronic and ligand effects. DFT calculations (Figure 10) show that there is a charge transfer between $\mathrm{Cu}$ and $\mathrm{Ni} / \mathrm{Co}$, increasing the positive charge of the $\mathrm{Cu}$ centers. As a consequence, the electron transfer from the carbon support to the $\mathrm{Cu}$ ions is facilited compared to pure $\mathrm{Cu}-\mathrm{POM}$, enhancing the ORR activity. In addition, the charge density of $\mathrm{Cu}$ is less positive for $\mathrm{Cu}_{6} \mathrm{Co}_{7}$ (0.760) than for $\mathrm{Cu}_{6} \mathrm{Ni}_{7}(0.808)$, leading to a more efficient electron transfer from the carbon support to the POM for $\mathrm{Cu}_{6} \mathrm{Ni}_{7}$ and then to a higher ORR catalytic activity for this compound. This charge transfer effect can also be evidenced considering the XPS spectra of the POM/TTF-F hybrids (Figure S22). In Figure S22, the dotted lines denote the averaged binding energies for the $\mathrm{Cu} 2 \mathrm{p} 5 / 2$ and $2 \mathrm{p} 3 / 2$ peaks corresponding to $\mathrm{Cu}_{3} \mathrm{P}_{2} \mathrm{~W}_{18} / \mathrm{TTF}-\mathrm{F}$. Significant negative shifts in these binding energies are observed for both $\mathrm{Cu}_{6} \mathrm{Ni}_{7} / \mathrm{TTF}-\mathrm{F}$ and $\mathrm{Cu}_{6} \mathrm{Co}_{7} / \mathrm{TTF}-\mathrm{F}$, revealing that the incorporation of $\mathrm{Ni}$ or $\mathrm{Co}$ induces an electron density increase on the $\mathrm{Cu}$ atoms. In addition, $\mathrm{Cu}_{6} \mathrm{Ni}_{7} / \mathrm{TTF}-\mathrm{F}$ exhibits lower binding energies than $\mathrm{Cu}_{6} \mathrm{Co}_{7} /$ TTF-F. This is indicative of a higher charge transfer from TTF-F to $\mathrm{Cu}$ in $\mathrm{Cu}_{6} \mathrm{Ni}_{7} / \mathrm{TTF}-\mathrm{F}$ than in $\mathrm{Cu}_{6} \mathrm{Co}_{7} / \mathrm{TTF}-\mathrm{F}$, in agreement with the DFT results. Thus, $\mathrm{Cu}_{6} \mathrm{Ni}_{7} / \mathrm{TTF}-\mathrm{F}$ exhibits significant synergistic effects in the ORR process.

(a)

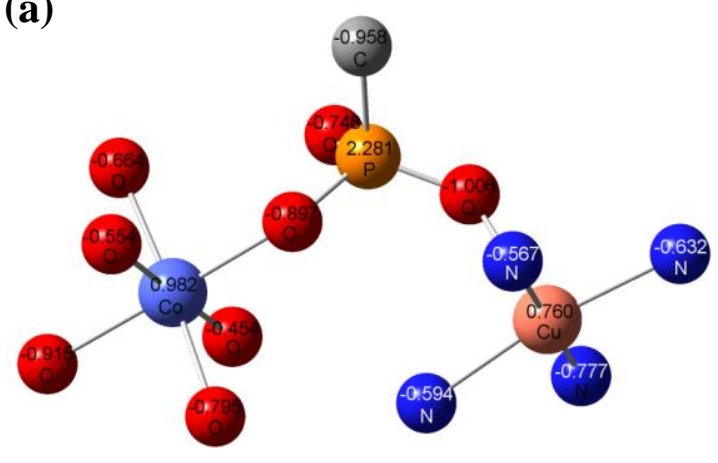

$\mathrm{Cu}_{6} \mathrm{Co}_{7}$ fragment (b)

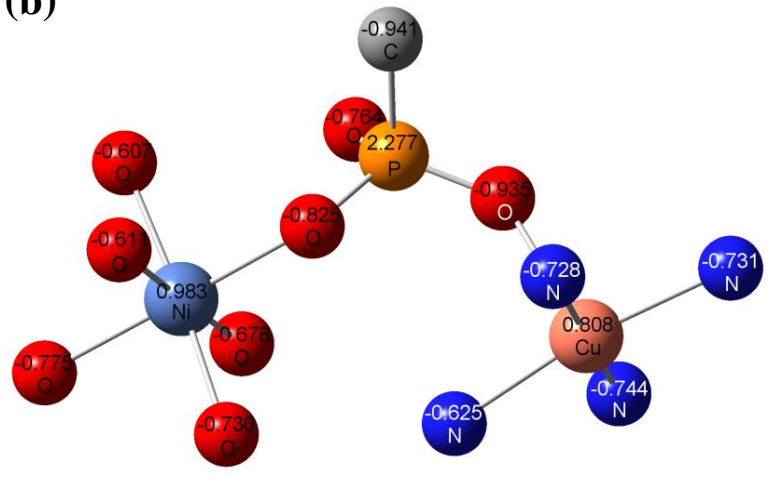

$\mathrm{Cu}_{6} \mathrm{Ni}_{7}$ fragment

Figure 10. DFT-calculated charge density distribution for (a) $\mathrm{Cu}_{6} \mathrm{Ni}_{7}$ and (b) $\mathrm{Cu}_{6} \mathrm{Co}_{7}$. 
We tried to find active sites from both the experimental data and DFT calculations. First of all, it is clear from comparison of the activities of $\mathrm{Cu}_{6} \mathrm{Ni}_{7}$ and $\mathrm{Cu}_{6} \mathrm{Co}_{7}$ that the $3 \mathrm{~d}$ transition metals embedded in the POM play a role in the determination of the ORR activity of the catalyst. If we look more closely to the molecular structure of $\mathrm{Cu}_{6} \mathrm{Ni}_{7}$, we can find that six $\mathrm{Cu}$ atoms are located at outside of POM sphere, which made them more suitable to react with oxygen. Also, DFT calculations revealed that charge densities on the $\mathrm{Cu}$ atoms are higher for $\mathrm{Cu}_{6} \mathrm{Ni}_{7}$ than for $\mathrm{Cu}_{6} \mathrm{Co}_{7}$, facilitating the reaction with oxygen. Thus $\mathrm{Cu}$ is the most possible active sites in POMs for ORR catalysis.

We show here the first outstanding ORR electrocatalysis driven partly by synergistic cooperation of two non-noble metal centers within a POM. It is worth noting that even the observation of efficient Ni-substituted POMs for the ORR electrocatalysis is unprecedented.

\section{CONCLUSION}

In conclusion, we reported herein on a new approach for the fabrication of noble metal-free ORR electrocatalysts based on 3d-substituted POMs synthesized in two steps, a classical coordination complexes $\left(\left[\mathrm{Cu}(\mathrm{en})_{2}\right]^{2+}\right.$ ) and commercial (carbon Vulcan XC-72) or easy-to-prepare carbonaceous (graphene oxide, TTF-F) materials. It has been evidenced that the association of POMs with very simple coordination complexes can enhance the ORR activity of such composite either in basic or neutral media. In particular, the overpotential required to drive the ORR for the composite associating the $\left\{\left(\mathrm{PW}_{9}\right)_{2} \mathrm{Ni}_{7}\right\} \mathrm{POM},\left[\mathrm{Cu}(\text { ethylenediamine })_{2}\right]^{2+}$ and the highly conductive and ORR active TTF-F carbonaceous material is very close to that of Pt/C. Moreover, these ORR heterogeneous electrocatalysts exhibit much higher durability. It has been shown that the high activity of the reported composites is due both to the binary combination of 
$\mathrm{Cu}^{\mathrm{II}}$ and $\mathrm{Ni}^{\mathrm{II}}$ cations and to the strong interaction between the carbonaceous support and the deposited species. To our knowledge, $\mathrm{Cu}_{6} \mathrm{Ni}_{7} / \mathrm{TTF}-\mathrm{F}, \mathrm{Cu}_{6} \mathrm{Ni}_{7} / \mathrm{rGO}$ and $\mathrm{Cu}_{6} \mathrm{Ni}_{7} / \mathrm{C}$ are the first examples of POM-based electrocatalysts able to promote one-step reduction of oxygen to water in neutral medium. This approach also paves the way for the development of a whole new family of efficient noble metal-free ORR electrocatalysts. The nature of the cationic coordination complex associated to the POM has to be optimized. ${ }^{53}$ The nature of the $\mathrm{Ni}^{\mathrm{II}} \mathrm{POM}$ (W/Ni ratio, number of accessible sites on the $\mathrm{Ni}^{\mathrm{II}}$ centers) has also to be modulated. ${ }^{40}$ This work is currently under study.

ASSOCIATED CONTENT

\section{Supporting Information.}

A detailed experimental section including the synthesis of all the compounds reported herein, X-ray Diffraction data, additional SEM, TEM images, XPS spectra, complementary electrochemical and electrocatalytic methods and data. This material is available free of charge via the Internet at http://pubs.acs.org.

\section{AUTHOR INFORMATION}

\section{Corresponding Author}

*E-mails: hyhe@ipe.ac.cn., pierre.mialane@uvsq.fr (P.M.) and zhanggj@ipe.ac.cn (G.Z.)

\section{Author Contributions}

The manuscript was written through contributions of all authors. All authors have given approval to the final version of the manuscript.

\section{Notes}


The authors declare no competing financial interest.

\section{ACKNOWLEDGMENT}

This work was supported by the National Natural Science Foundation of China (No. 91545125 and U1662121), Youth Innovation Promotion Association of CAS, the CNRS, the Ministère de l'Enseignement Supérieur et de la Recherche, the Université Paris-Saclay, the Université de Versailles Saint-Quentin.

\section{REFERENCES}

(1) Iwase, K.; Yoshioka, T.; Nakanishi, S.; Hashimoto, K.; Kamiya, K. Copper-Modified Covalent Triazine Frameworks as Non-Noble-Metal Electrocatalysts for Oxygen Reduction. Angew. Chem. Int. Ed. 2015, 54, 11068-11072.

(2) Cheng, F.; Chen, J. Metal-Air Batteries: from Oxygen Reduction Electrochemistry to Cathode Catalysts. Chem. Soc. Rev. 2012, 41, 2172-2192.

(3) Bruce, P. G.; Freunberger, S. A.; Hardwick, L. J.; Tarascon, J.-M. Li-O $\mathrm{O}_{2}$ and Li-S Batteries with High Energy Storage. Nat. Mater. 2012, 11, 19-29.

(4) Kirubakaran, A.; Jain, S.; Nema, R. K. A Review on Fuel Cell Technologies and Power Electronic Interface. Ren. Sust. Ener. Rev. 2009, 13, 2430-2440.

(5) Yang, Z.; Zhou, X.; Jin, Z.; Liu, Z.; Nie, H.; Chen, X.; Huang, X. A Facile and General Approach for the Direct Fabrication of 3D, Vertically Aligned Carbon Nanotube Array/Transition Metal Oxide Composites as Non-Pt Catalysts for Oxygen Reduction Reactions. Adv. Mater. 2014, 26, 3156-3161.

(6) Yang, Z.; Yao, Z.; Li, G.; Fang, G.; Nie, H.; Liu, Z.; Zhou, X.; Chen, X.; Huang, S. SulfurDoped Graphene as an Efficient Metal-free Cathode Catalyst for Oxygen Reduction. ACS Nano 2012, 6, 205-211.

(7) Yang, Z.; Nie, H.; Chen, X.; Chen, X.; Huang, S. Recent Progress in Doped Carbon Nanomaterials as Effective Cathode Catalysts for Fuel Cell Oxygen Reduction Reaction. $J$. Power Sources 2013, 236, 238-249.

(8) Nie, Y.; Li, L.; Wei, Z. Recent Advancements in Pt and Pt-Free Catalysts for Oxygen Reduction Reaction. Chem. Soc. Rev. 2015, 44, 2168-2201.

(9) Wu, G.; More, K. L.; Johnston, C. M.; Zelenay, P. Highperformance Electrocatalysts for Oxygen Reduction Derived from Polyaniline, Iron, and Cobalt. Science 2011, 332, 443-447. 
(10) Lee, J.-S.; Park, G. S.; Lee, H. I.; Kim, S. T.; Cao, R.; Liu, M.; Cho, J. Ketjenblack Carbon Supported Amorphous Manganese Oxides Nanowires as Highly Efficient Electrocatalyst for Oxygen Reduction Reaction in Alkaline Solutions. Nano Lett. 2011, 11, 5362-5366.

(11) Cui, X.; Hua, Z.; Chen, L.; Zhang, X.; Chen, H.; Shi, J. Manganese Oxide NanorodDecorated Mesoporous ZSM-5 Composite as a Precious-Metal-Free Electrode Catalyst for Oxygen Reduction. ChemSusChem 2016, 9, 1010-1019.

(12) Yang, Z.; Zhou, X.; Nie, H.; Yao, Z.; Huang, S. Facile Construction of Manganese Oxide Doped Carbon Nanotube Catalysts with High Activity for Oxygen Reduction Reaction and Investigations into the Origin of their Activity Enhancement. ACS Appl. Mater. Interfaces 2011, 3, 2601-2606.

(13) Liang, Y.; Wang, H.; Diao, P.; Chang, W.; Hong, G.; Li, Y.; Gong, M.; Xie, L.; Zhou, J.; Wang, J.; Regier, T. Z.; Wei, F.; Dai, H. Oxygen Reduction Electrocatalyst Based on Strongly Coupled Cobalt Oxide Nanocrystals and Carbon Nanotubes. J. Am. Chem. Soc. 2012, 134, 15849-15857.

(14) Cheng, F.; Zhang, T.; Zhang, Y.; Du, J.; Han, X.; Chen, J. Enhancing Electrocatalytic Oxygen Reduction on $\mathrm{MnO}_{2}$ with Vacancies. Angew. Chem. Int. Ed. 2013, 52, 2474-2477.

(15) Miras, H. N.; Yan, J.; Long, D.-L.; Cronin, L. Engineering Polyoxometalates with Emergent Properties. Chem. Soc. Rev. 2012, 41, 7403-7430.

(16) Wang, S.-S.; Yang, G.-Y. Recent Advances in Polyoxometalate-Catalyzed Reactions. Chem. Rev. 2015, 115, 4893-4962.

(17) Proust, A.; Matt, B.; Villanneau, R.; Guillemot, G.; Gouzerh, P.; Izzet, G. Functionalization and Post-Functionalization: A Step Towards Polyoxometalate-Based Materials. Chem. Soc. Rev. 2012, 41, 7605-7622.

(18) Sartorel, A.; Bonchio, M.; Campagna, S.; Scandola, F. Tetrametallic Molecular Catalysts for Photochemical Water Oxidation. Chem. Soc. Rev. 2013, 42, 2262-2280.

(19) Bassil, Bassem S.; Kortz, U. Recent Advances in Lanthanide-Containing Polyoxotungstates. Z. Anorg. Allg. Chem. 2010, 636, 2222-2231.

(20) Muller, A.; Gouzerh, P. From Linking of Metal-Oxide Building Blocks in A Dynamic Library to Giant Clusters with Unique Properties and Towards Adaptive Chemistry. Chem. Soc. Rev. 2012, 41, 7431-7463.

(21) Lv, H.; Geletii, Y. V.; Zhao, C.; Vickers, J. W.; Zhu, G.; Luo, Z.; Song, J.; Lian, T.; Musaev, D. G.; Hill, C. L. Chem. Soc. Rev. 2012, 41, 7572-7589.

(22) Oms, O.; Dolbecq, A.; Mialane, P. Diversity in Structures and Properties of 3dIncorporating Polyoxotungstates. Chem. Soc. Rev. 2012, 41, 7497-7536.

(23) Ji, Y.; Huang, L.; Hu, J.; Streb, C.; Song, Y.-F. Polyoxometalate-Functionalized Nanocarbon Naterials for Energy Conversion, Energy Storage and Sensor Systems. Energy Environ. Sci. 2015, 8, 776-789. 
(24) Toma, F.; Sartorel, A.; Iurlo, M.; Carraro, M.; Parisse, P.; Maccato, C.; Rapino, S.; Benito Gonzalez, R.; Amenitsch, H.; Ros, T.; Casalis, L.; Goldoni, A.; Marcaccio, M.; Scorrano, G.; Scoles, G.; Paolucci, F.; Prato1, M.; Bonchio, M. Efficient Water Oxidation at Carbon Nanotube-Polyoxometalate Electrocatalytic Interfaces. Nat. Chem. 2010, 2, 826-831.

(25) Zou, C.; Zhang, Z.; Xu, X.; Gong, Q.; Jing Li, J.; Wu, C. A Multifunctional

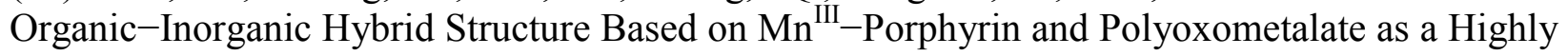
Effective Dye Scavenger and Heterogenous Catalyst. J. Am. Chem. Soc. 2012, 134, 87-90.

(26) Wang, S.; Yang, G. Recent Advances in Polyoxometalate-Catalyzed Reactions. Chem. Rev. 2015, 115, 4893-4962.

(27) Lv, H.; Geletii, Y.; Zhao, C.; Vickers, J.; Zhu, G.; Luo, Z.; Song, J.; Lian, T.; Musaevb, D. Hill, C. Polyoxometalate Water Oxidation Catalysts and theProduction of Green Fuel. Chem. Soc. Rev. 2012, 41, 7572-7589.

(28) Skunik, M.; Chojak, Ma.; Rutkowska, I. A.; Kulesza, P. J. Improved Capacitance Characteristics During Electrochemical Charging of Carbon Nanotubes Modified with Polyoxometallate Monolayers. Electrochimica Acta 2008, 53, 3862-3869.

(29) Skunik M.; Baranowska B.; Fattakhova D.; Miecznikowski K.; Chojak M.; Kuhn A. Electrochemical Charging and Electrocatalysis at Hybrid Films of Polymer-Interconnected Polyoxometallate-Stabilized Carbon Submicroparticles. J. Solid State Electrochem. 2006, 10, 168-175.

(30) Garrigue P.; Delville M.-H.; Labrugère C.; Cloutet E.; Kulesza P. J.; Morand J. P.; Kuhn A. Top-Down Approach for the Preparation of Colloidal Carbon Nanoparticles. Chem. Mater. 2004, $16,2984-2986$.

(31) Rousseau, G.; Zhang, S.; Oms, O.; Dolbecq, A.; Marrot, J.; Liu, R.; Shang, X.; Zhang, G.; Keita, B.; Mialane, P. Sequential Synthesis of $3 \mathrm{~d}-3 \mathrm{~d}, 3 \mathrm{~d}-4 \mathrm{~d}$, and $3 \mathrm{~d}-5 \mathrm{~d}$ Hybrid Polyoxometalates and Application to the Electrocatalytic Oxygen Reduction Reactions. Chem. Eur. J. 2015, 21, 12153-12160.

(32) Hao, L.; Zhang, S.; Liu, R.; Ning, J.; Zhang, G.; Zhi, L. Bottom-Up Construction of Triazine-Based Frameworks as Metal-Free Electrocatalysts for Oxygen Reduction Reaction. Adv. Mater. 2015, 27, 3189-3195.

(33) Ginsberg A. P. Inorganic Syntheses, John Wiley and Sons: New York 1990, Vol. 27.

(34) Kubíček V.; Kotek J.; Hermann P.; Lukeš I. Aminoalkylbis(phosphonates): Their Complexation Properties in Solution and in the Solid State. Eur. J. Inorg. Chem. 2007, 2, 333344.

(35) El Moll, H.; Dolbecq, A.; Marrot, J.; Rousseau, G.; Haouas, M.; Taulelle, F.; Rogez, G.; Wernsdorfer, W.; Keita, B.; Mialane, P. A Stable Hybrid Bisphosphonate Polyoxometalate Single-Molecule Magnet. Chem. Eur. J. 2012, 18, 3845-3849. 
(36) El Moll, H.; Rousseau, G.; Dolbecq, A.; Oms, O.; Marrot, J.; Haouas, M.; Taulelle, F.; Rivière, E.; Wernsdorfer, W.; Lachkar, D.; Lacôte, E.; Keita, B.; Mialane, P. Properties of a Tunable Multinuclear Nickel Polyoxotungstate Platform. Chem. Eur. J. 2013, 19, 6753-6765.

(37) Sheldrick G. M. SADABS, Program for Scaling and Correction of Area Detector Data, University of Göttingen, Germany, 1997.

(38) Blessing, R. A Empirical Correction for Absorption Anisotropy. Acta Crystallogr. 1995, A51, 33-38.

(39) Sheldrick G. M. SHELX-TL, Software Package for the Crystal Structure Determination, Siemens Analytical X-ray Instrument Division, Madison, WI USA, 1994.

(40) For reviews on 3d-subtituted polyoxotungstates, see (a) Zheng, S.-T.; Yang, G.-Y. Recent Advances in Paramagnetic-TM-Substituted Polyoxometalates (TM = Mn, Fe, Co, Ni, Cu). Chem. Soc. Rev. 2012, 41, 7623-7646. (b) Oms, O.; Dolbecq, A.; Mialane, P. Diversity in Structures and Properties of 3d-Incorporating Polyoxotungstates. Chem. Soc. Rev. 2012, 41, 7497-7536.

(41) Li, C. W.; Kanan, M. W. $\mathrm{CO}_{2}$ Reduction at Low Overpotential on Cu Electrodes Resulting from the Reduction of Thick $\mathrm{Cu}_{2} \mathrm{O}$ Films. J. Am. Chem. Soc. 2012, 134, 7231-7234.

(42) Zheng, Y.-L.; Mao, D.-S.; Sun, S.-S.; Fu, G.-Y. Solvothermal Synthesis in Ethylene Glycol and Catalytic Activity for $\mathrm{CO}$ Oxidation of $\mathrm{CuO} / \mathrm{CeO}_{2}$ Catalysts. J. Mater. Sci. 2016, 51, 917925.

(43) Wang, F.-F.; Wei, P.-J.; Yu, G.-Q.; Liu, J.-G. Titanium Dioxide-Grafted Copper Complexes: High-Performance Electrocatalysts for the Oxygen Reduction Reaction in Alkaline Media. Chem. Eur. J. 2016, 22, 382-389.

(44) Wu, X.; Chen, F.; Zhang, N.; Qaseem, A.; Johnston, R. L. A Silver-Copper Metallic Glass Electrocatalyst with High Activity and Stability Comparable to Pt/C for Zinc-Air Batteries. $J$. Mater. Chem. A 2016, 4, 3527-3537.

(45) Yang, L.; Gao, M.; Dai, B.; Guo, X.; Liu, Z.; Peng, B. An Efficient NiS@N/S-C Hybrid Oxygen Evolution Electrocatalyst Derived from Metal-Organic Framework. Electrochim. Acta 2016, 191, 813-820.

(46) Zhang, X.; Xu, H.; Li, X.; Li, Y.; Yang, T.; Liang, Y. Facile Synthesis of NickelIron/Nanocarbon Hybrids as Advanced Electrocatalysts for Efficient Water Splitting. ACS Catal. 2016, 6, 580-588.

(47) Wang, C.; Zhai, P.; Zhang, Z.; Zhou, Y.; Zhang, J.; Zhang, H.; Shi, Z.; Han, R. P. S.; Huang, F.; Ma, D. Nickel Catalyst Stabilization via Graphene Encapsulation for Enhanced Methanation Reaction. J. Catal. 2016, 334, 42-51.

(48) Liu, X.; Wang, D.; Li, Y. Synthesis and Catalytic Properties of Bimetallic Nanomaterials with Various Architectures. Nano Today 2012, 7, 448-466. 
(49) Ben Liew, K.; Daud, W. R. W.; Ghasemi, M.; Leong, J. X.; Su Lim, S.; Ismail, M. Non-Pt Catalyst as Oxygen Reduction Reaction in Microbial Fuel Cells: A Review. Int. J. Hydrogen Energy 2014, 39, 4870-4883.

(50) Xia, B.Y.; Yan, Y.; Wang, X.; Lou, X. W. Recent Progress on Graphene-Based Hybrid Electrocatalysts. Mater. Horiz. 2014, 1, 379-399.

(51) Liu, R.; Zhang, G.; Cao, H.; Zhang, S.; Xie, Y.; Haider, A.; Kortz, U.; Chen, B.; Dalal, N. S.; Zhao, Y.; Zhi, L.; Wu, C.-X.; Yan, L.-K.; Su, Z.; Keita, B. Enhanced Proton and Electron Reservoir Abilities of Polyoxometalate Grafted on Graphene for High-Performance Hydrogen Evolution. Energy Environ. Sci. 2016, 9, 1012-1023.

(52) Pichon, C.; Mialane, P.; Dolbecq, A.; Marrot, J.; Rivière, E.; Keita, B.; Nadjo, L.; Sécheresse, F. Characterization and Electrochemical Properties of Molecular Icosanuclear and Bidimensional Hexanuclear Cu(II) Azido Polyoxometalates. Inorg. Chem. 2007, 46, 5292-5301.

(53) He, W.; Wang, Y.; Jiang, C.; Lu, L. Structural Effects of a Carbon Matrix in Non-Precious Metal $\mathrm{O}_{2}$-Reduction Electrocatalysts. Chem. Soc. Rev. 2016, 45, 2396-2409. 
TOC: Composites made of polyoxometalates, classical coordination complexes and highly conducting carbonaceous materials exhibit higher Oxygen Reaction Reduction electrocatalytic performances than those of commercial Pt/C in neutral medium.

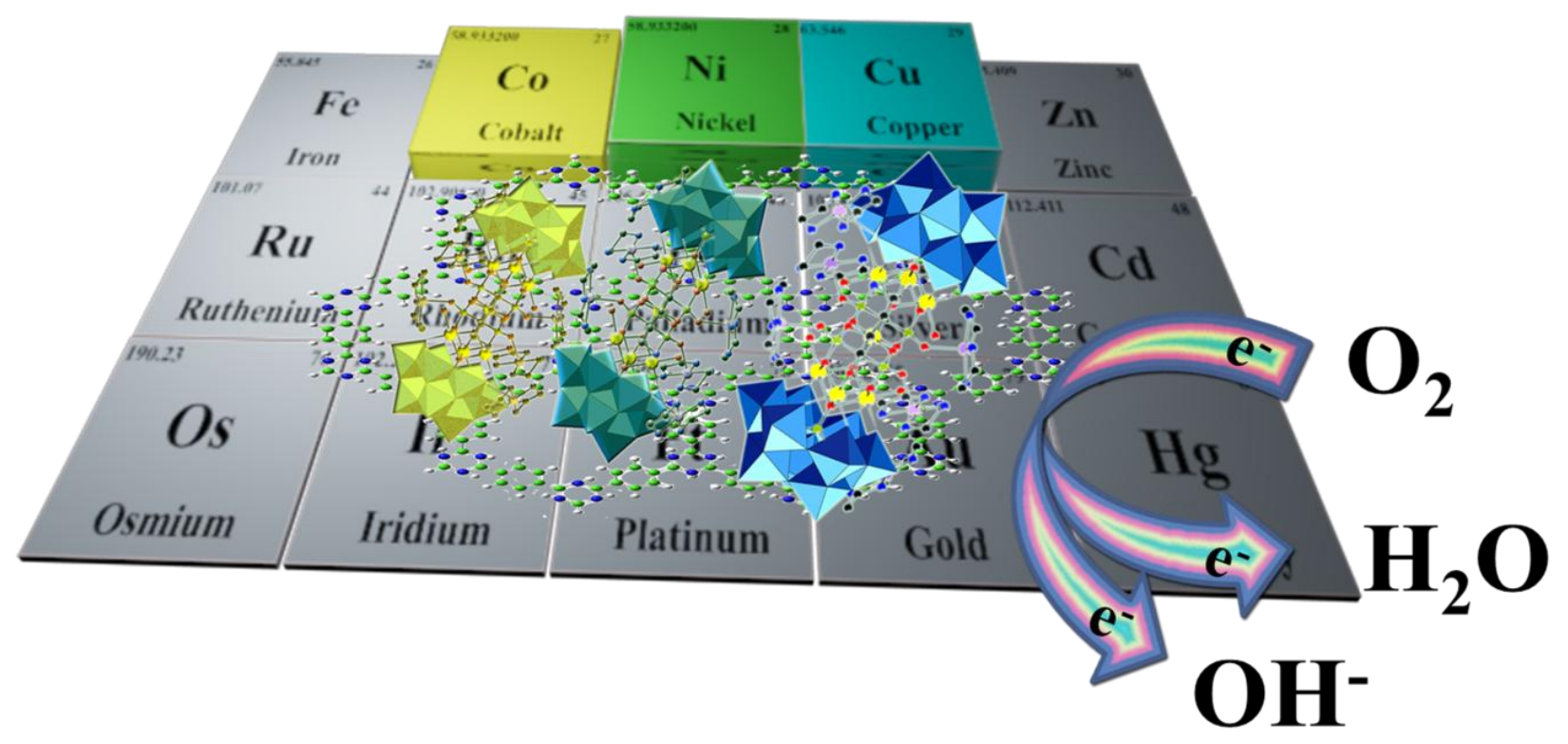

